Fault textures in volcanic conduits

\title{
Fault textures in volcanic conduits: evidence for seismic trigger mechanisms during silicic eruptions
}

\author{
Hugh Tuffen*, Don Dingwell \\ Department of Earth and Environmental Sciences, University of Munich, \\ Theresienstraße 41, D-80333 Munich, Germany. \\ *Corresponding author. \\ Telephone: $\quad+49892180-4271$ \\ Fax: $\quad+49892180-4176$ \\ Email: $\quad$ tuffen@min.uni-muenchen.de
}

Manuscript published in Bulletin of Volcanology 2005 
Fault textures in volcanic conduits

\section{Abstract}

It is proposed that fault textures in two dissected rhyolitic conduits in Iceland preserve evidence for shallow seismogenic faulting within rising magma during the emplacement of highly viscous lava flows. Detailed field and petrographic analysis of such textures may shed light on the origin of long-period and hybrid volcanic earthquakes at active volcanoes. There is evidence at each conduit investigated for multiple seismogenic cycles, each of which involved four distinct evolutionary phases. In phase 1, shear fracture of unrelaxed magma was triggered by shear stress accumulation during viscous flow, forming the angular fracture networks that initiated faulting cycles. Transient pressure gradients were generated as the fractures opened, which led to fluidisation and clastic deposition of fine-grained particles that were derived from the fracture walls by abrasion. Fracture networks then progressively coalesced and rotated during subsequent slip (phase 2), developing into cataclasite zones with evidence for multiple localised slip events, fluidisation, and grain size reduction. Phase 2 textures closely resemble those formed on seismogenic tectonic faults characterised by friction-controlled stick-slip behaviour. Increasing cohesion of cataclasites then led to aseismic, distributed ductile deformation (phase 3) and generated deformed cataclasite zones, which are enriched in metallic oxide microlites and resemble glassy pseudotachylite. Continued annealing and deformation eventually erased all structures in the cataclasite and formed microlite-rich flow bands in obsidian (phase 4). Overall, the mixed brittle-ductile textures formed in the magma appear similar to those formed in lower crustal rocks close to the brittleductile transition, with the rheological response mediated by strain rate variations and frictional heating.

Fault processes in highly viscous magma are compared to those elsewhere in the crust, and this comparison is used to appraise existing models of volcano seismic activity. Based on the textures observed, it is suggested that patterns of long-period and hybrid 
Fault textures in volcanic conduits

earthquakes at silicic lava domes reflect friction-controlled stick-slip movement and eventual healing of fault zones in magma, which are an accelerated and smaller-scale analogue of tectonic faults.

Keywords: Volcano seismicity, Fault processes, Brittle-ductile transition, Conduit flow, Obsidian, Fracture, Welding

\section{Introduction}

Textures on seismogenic faults

Extensive studies of the microtextures in seismogenic fault zones have been carried out in the last two decades, with the objective of linking field evidence to the mechanisms of rupture, slip and healing that control the occurrence and nature of seismic events (e.g. Chester and Logan 1986; Sibson 1986; Lin 1996; Chester and Chester 1998; Curewitz and Karson 1999; Fabbri et al. 2000; Otsuki et al. 2003; Warr et al. 2003; Wilson et al. 2003, Crider and Peacock 2004). Detailed observations of the Punchbowl Fault, California have shown that textures in cataclasite record repeated slip events on a longlived fault zone and represent a complex collage formed during past seismicity (Chester and Logan 1986; Chester and Chester 1998; Wilson et al. 2003). This work complements recent seismic models, which propose that the vast majority of seismic events are triggered by slip on existing faults, and are thus controlled by frictional resistance to slip, rather than the fracture strength of intact rock (e.g. Scholz 1998). Fault zones are initiated by shear on pre-existing or precursor structures, and mature during subsequent slip by wear, linkage and coalescence, eventually forming through-going zones of localised slip (Chester and Chester 1998; Vermilye and Scholz 1998; Ben Zion 
Fault textures in volcanic conduits

and Sammis 2003; Kilburn 2003, Crider and Peacock 2004). The repeat time of earthquakes on each fault then depends upon time-dependent fault strength and the rate of loading (Dietrich 1979; Karner and Marone 1998; Marone 1998). Field observations have been complemented by a wealth of experimental simulations of the textural evolution of cataclasite, or fault gouge, during friction-controlled slip (e.g. Byerlee et al. 1978; Marone and Scholz 1989; Karner and Marone 1998), which have successfully recreated localised shear zones, grain size reduction, and monitored the evolution of fault strength at different applied loads.

Although there are no unambiguous indicators for former seismogenic faulting, the following features are considered to be indicative of seismogenic slip: fluidisation of cataclasite, injection structures, and presence of pseudotachylite (Sibson 1975, 1986; Lin 1996; Chester and Chester 1998; Curewitz and Karson 1999). All are likely to be related to the abrupt variations in fault-normal stress that are thought to accompany dynamic rupture and lead to the radiation of seismic energy (Ben Zion 2001 and references therein). Injection of veins of pseudotachylite are thought to form at fault zones when stress perturbations around shear planes lead to tensile failure of their walls, at the same time as abrasion and frictional melting occur on the shear planes (e.g. Lin 1996; Curewitz and Karson 1999). Fluidisation of cataclasite can be triggered by acoustic energy release during rupture (Melosh 1996) and by dilation of close-packed particulate material as fault zones widen during slip (Monzawa and Otsuki 2003).

In this paper we will highlight the remarkable similarities between fault textures in obsidian and those elsewhere in the crust. We will propose that shallow faulting of rising magma is an important and widespread mechanism at lava domes, which may trigger long-period earthquakes, influence degassing patterns, and control the flow behaviour of the magma. 
Fault textures in volcanic conduits

Mixed brittle-ductile deformation: the importance of strain rate

Although most studies of fault textures have focussed on purely brittle deformation in relatively cool crystalline igneous or sedimentary rocks at fairly shallow crustal levels (e.g. Chester and Chester 1998), mixed brittle-ductile textures have also been described from greater crustal depths (Hobbs et al. 1986; Simpson 1986; Stel 1986; Takagi et al. 2000) and from frictional melting of shallow crust during faulting (e.g. Sibson 1975, Curewitz and Karson 1999). Crosscutting generations of cataclasite [indicative of brittle deformation] and mylonite [ductile deformation] are thought to indicate cyclic strainrate-dependent brittle-ductile behaviour (Stel 1986; Takagi et al. 2000). Brittle deformation events are triggered by the sudden jumps in strain rate that occur when ruptures originating in the overlying brittle crust propagate downwards into normally ductile material (Hobbs et al. 1986; Stel 1986). They are superimposed on the slower "background" strain rate, which is accommodated by ductile deformation processes such as dislocation creep and dynamic recystallisation.

This mixed brittle-ductile deformation can also be understood in terms of rateand state-dependent friction theory; the brittle events are triggered when a velocity jump is sufficient to move the material from the stable, velocity-strengthening regime into the unstable, velocity-weakening regime (e.g. Scholz 1998). After the passage of the transient velocity jump, the brittly deformed material re-enters the stable regime and undergoes such thorough healing and restrengthening that it is no longer a favourable plane of weakness, and any subsequent brittle event is likely to cut across it.

Such rate-dependent brittle-ductile deformation of the crystalline crust has an analogue in the rate-dependent brittle-ductile behaviour of silicate melt in the glass transition interval (e.g. Dingwell and Webb 1989; Dingwell 1996, 1997), although the mechanisms of deformation differ in detail (dislocation creep vs. viscous shear of melt). 
Fault textures in volcanic conduits

In both cases, the strain rate and material properties of the deforming medium determine whether deformation is ductile or brittle. To date, consideration of ductile-brittle crustal behaviour has involved study of the temperature-dependent rheology of granite (e.g. Stesky et al. 1974). Ductile deformation in the granitic crust occurs through creep deformation of crystal phases, of which quartz deforms most readily at $300{ }^{\circ} \mathrm{C}$ (Stesky et al. 1974). This has led to models of the depth of seismogenic faulting in the continental crust, based on the expected temperature distribution and depth-dependent rheological response to tectonically-driven strain rates (e.g. Lamontagne and Ranalli 1996; Gratier et al. 1999). Similarly, magma exhibits relaxed, liquid-like behaviour at temperatures above the glass transitional interval, mixed brittle-ductile behaviour within the glass transitional interval, depending upon the strain rate, and purely brittle behaviour at lower temperatures (Dingwell 1996, 1997). Therefore, the spatial and temporal distribution of strain rate and temperature within deforming magma, as in the crust as a whole, will determine patterns of brittle-ductile behaviour. As argued below, strain-rate pulses within highly viscous, silicic-rich deforming magma also may trigger abrupt brittle events that are superimposed onto longer-term ductile deformation, and as a result generate patterns of seismicity observed at active lava domes, as well as flow banding in obsidian.

Volcano seismicity and brittle magma deformation

The body of magma in an erupting volcano and the surrounding country rock are the site of intense seismic activity as magma rises to the surface, especially during the effusion of highly viscous lava domes (e.g. Chouet 1996; Miller et al. 1998, Neuberg 2000; Umakoshi et al. 2002). As such, they represent parts of the crust with exceptionally high seismic energy production. Many eruptions, especially prolonged dome-building 
Fault textures in volcanic conduits

eruptions with a compositional range between basaltic andesite and rhyolite, are accompanied by repetitive long-period (LP), hybrid and volcano-tectonic (VT) earthquakes with moment magnitudes between -1 and 3 , which are thought to originate in a small volume of the volcanic edifice, either in or adjacent to the conduit, at a depth of $<2$ km (e.g. Lahr et al. 1994; Chouet 1996; Stix et al. 1997; Gil Cruz and Chouet 1997; White et al. 1998; Hidayat et al. 2000; McNutt 2000; Neuberg 2000; Uchida and Sakai 2002; Umakoshi et al. 2002, 2003). Hybrid and LP events show no S-wave arrivals, and the frequency content is mostly restricted in a narrow band between $1-3 \mathrm{~Hz}$ (e.g. White et al. 1998; Neuberg 2000). Swarms of hybrid events are a characteristic feature of dome eruptions, consisting of hundreds to tens of thousands of near-identical events over a timescale of hours to weeks (Miller et al. 1998, White et al. 1998; Umakoshi et al. 2002, 2003, Molina et al. 2004). VT events have higher frequency content and S-wave arrivals, and resemble small tectonic events (e.g. Lahr et al. 1994, Miller et al. 1998).

Although there is a common belief that these earthquakes are intrinsically linked to the flow dynamics of the rising magma, opinions have differed over the past decade as to whether magma-water interaction, stick-slip motion, shear fracture or episodic gas loss is the trigger mechanism (Chouet 1988; Goto 1999; White et al. 1998; Hidayat et al. 2000; Kumagai and Chouet 2000; Neuberg 2000; Uchida and Sakai 2002; Umakoshi et al. 2002). For example, Kumagai and Chouet (2000) have suggested that resonance of cracks containing ash and gas can create seismic signals with the spectral characteristics of observed hybrid and long-period events, whereas Sturton and Neuberg (2003) and Jousset et al. (2003) show how the same spectra can be generated by resonance of the entire fluid-filled conduit. In both cases, the triggering mechanism for such resonance has remained elusive. However, there is increasing evidence that shear fracture of rising magma is a plausible trigger mechanism in many cases, based on field evidence for 
Fault textures in volcanic conduits

repeated fracture of magma within conduits (Tuffen et al. 2002b, 2003), analysis of high-quality seismic data (Uchida and Sakai 2002; Umakoshi et al. 2002, 2003), and simple models of shear fracture during conduit flow (Goto 1999; Gonnerman and Manga 2003; Tuffen et al. 2003). Such shear fracture models require the presence of highly viscous magma in the conduit that can undergo solid-like brittle behaviour, possibly juxtaposed with less viscous magma that can act as a fluid-like seismic resonator (Neuberg et al. 2003).

Volcano-tectonic events are commonly attributed to fracture of the country rock as a preparatory process for ascent of magma, and may occur over a greater depth range than LP and hybrid events (e.g. Lahr et al. 1994, Chouet 1996, Kilburn 2003).

Given that the connection between "tectonic" fault zones in the crust and earthquakes has been long recognised, it may appear somewhat surprising that no such link had been made for volcano seismicity. The reasons for this are threefold; first, because volcanoes are highly unstable zones of intense hydrothermal alteration, making preservation and recognition of fault textures unlikely except in exceptional circumstances. Second, given the instability of volcanic edifices and the flow of highpressure fluids through them, there are clearly many different processes that are candidates for seismic triggers (Neuberg 2000). Third, study of the focal mechanism of volcano seismic events is greatly hampered by topographic scattering effects, spatially heterogeneous attenuation, the weakness and emergent onsets of seismic signals, and difficulty in acquiring continuous seismic data from stations sufficiently close to the earthquake source.

Recently, Tuffen et al. (2003) reported that partial collapse of a young rhyolitic volcano in Iceland had fortuitously exposed a section of a near-pristine conduit, which contains the textural record of repeated fracturing and healing of magma as it rose to the surface. Their work showed that the time scale of the process and the seismic signals 
Fault textures in volcanic conduits

generated were consistent with long-period and hybrid seismicity. In this paper, we provide a more detailed description of this conduit and another nearby, and provide new textural evidence for faulting processes in magma. These observations are used to highlight striking similarities between fault textures in magma with those in seismogenic fault zones elsewhere in the crust.

\section{Geological setting and structure of the conduits}

Rauðufossafjöll is a subglacial peralkaline rhyolite volcanic complex at the western fringe of the Torfajökull central volcano, south-central Iceland (Figure 1a). It has a total volume of $\sim 6 \mathrm{~km}^{3}$ and comprises four flat-topped tuyas with altitudes around $1200 \mathrm{~m}$, which were erupted beneath ice at least $350 \mathrm{~m}$ thick, with numerous subglaciallyerupted ridges and lava flows (Tuffen 2001). Rauðufossafjöll is the largest of several complexes emplaced during a $\sim 60 \mathrm{ka}$ eruption of $11-17 \mathrm{~km}^{3}$ of magma from a number of fissures around the margins of the central volcano (McGarvie 1984). The southeastern tuya has a volume of $\sim 1 \mathrm{~km}^{3}$ and consists of a 300 m thick, poorly-exposed pedestal of subglacially-erupted pumiceous deposits overlain by three subaerial lava

flows (Figure 1b), which are between 8 and $100 \mathrm{~m}$ thick and have a total volume of $\sim 10^{7}$ $\mathrm{m}^{3}$ (Tuffen et al. 2002a). Partial collapse of the western flank of southeast Rauðufossafjöll, probably during deglaciation, has exposed a section through the lava flows in cliffs up to $100 \mathrm{~m}$ high, and, on the northern side of the edifice, two dike-like conduits that appear to have fed the northernmost lava flow. The conduits are aligned approximately SSW-NNE, roughly parallel to the majority of eruptive fissures in the Rauðufossafjöll complex, and are exposed at a depth of 10-40 m beneath the surface of the lava flow that they fed (Tuffen 2001; Tuffen et al. 2002a, 2002b, 2003). 
Fault textures in volcanic conduits

Figure 1

In this paper we describe textures in this conduit, which will henceforth be called Thumall Conduit (Icelandic for thumb), and another newly identified conduit in a loose scree gully 100 metres to the northeast, henceforth called Skriðugil Conduit (Icelandic for scree gully). The walls of the conduits are near parallel, both trending SSW-NNE, but not colinear, Skriðugil Conduit cropping out about $40 \mathrm{~m}$ to the east, and they may be connected at depth. Thumall Conduit is approximately 10 metres wide, and forms a 15 m-high finger that protrudes from the surrounding scree (Figure 2a). It is bounded to the east by a 5-m-thick obsidian wall, but the contact with the surrounding rock is not exposed. It is bounded to the west by a 5-m thick obsidian wall, but appears to grade into devitrified rhyolite to the north; the nature of the contact is ambiguous. Skriðugil Conduit is $15-20 \mathrm{~m}$ wide, and its brecciated outer walls are exposed to the east (Figure $2 b)$. Its western wall grades into the upper carapace of the lava flow.

Overall, the outcrops are interpreted as dike-like conduits rather than part of a lava flow/dome carapace (c.f. Manley 1996; Allen and McPhie 2003) because of their vertical flow features, which are not parallel to flow features in the main body of the lava, and their SSW-NNE orientations, which coincide with the local fissure orientation. However, due to erosion, the relationship between the conduits and the lava flows is ambiguous, and the conduits do not appear to have fed the bulk of the lava, but simply a small portion that flowed steeply downslope to the northeast.

\section{Figure 2}

Main textural zones of the conduits

Thumall Conduit consists of a devitrified, 4 m-wide microspherulitic interior flanked by 5 m-thick walls of dark grey-black obsidian (Figure 2a). Contacts between the obsidian and surrounding rock are not exposed, although the western wall appears to grade into devitrified lava. The majority of observations and samples were gathered from the cross- 
Fault textures in volcanic conduits

section shown in Figure 2a. The outer parts of the Thumall Conduit exposure consist of a zone of massive grey-black obsidian up to $5 \mathrm{~m}$ across (Figure $2 \mathrm{a}$ ), which contains $\sim 10$ $\%$ prominent euhedral phenocrysts of alkali feldspar, clinopyroxene, fayalite and magnetite up to $5 \mathrm{~mm}$ across. The obsidian is cut by numerous networks of anastomosing faults that vary between a few centimetres and 4.8 metres in length. It also contains pale grey cataclasite zones in various stages of healing and deformation, which are conspicuously devoid of intact phenocrysts. In general, cataclasite zones are more deformed towards the conduit centre, but undeformed fractures are found throughout the obsidian, including the innermost part of the conduit. The longest observed cataclasite band is $4.8 \mathrm{~m}$ in length, while widths vary from $<1 \mathrm{~mm}$ to $>80 \mathrm{~mm}$. The inner part of the conduit consists of grey-brown spherulitic rhyolite 2-4 m across (Figure 2a) with a phenocryst assemblage similar to the obsidian. The groundmass consists of overlapping spherulites $\sim 1 \mathrm{~mm}$ across. Trails of broken phenocrysts represent cataclasite zones subsequently overprinted by spherulitic textures. The contact with the obsidian is sharp on the east side, but gradational on the west side, with banded obsidian-devitrified rhyolite tens of centimetres thick between the two zones. Near-vertical platy fractures about 5-10 cm apart are locally developed and parallel to flow structures.

Skriðugil Conduit consists of a loose scree gully 40 metres in length and 15-20 metres across (Figure 2b, top centre). The central part of the conduit is less well exposed than the southern outcrop, but the contact between the obsidian wall and surrounding breccia is well exposed on the eastern side. A central 4 m-wide zone of obsidian containing $\sim 5 \%$ vesicles (labelled A) is flanked by vesicle-free obsidian $4 \mathrm{~m}$ wide (labelled B), which grades into an $8 \mathrm{~m}$-high screen of spherulitic, perlitised breccia to the east (labelled C), and spherulitic lava to the west (labelled D). The northern part of the gully is inaccessible. 
Fault textures in volcanic conduits

\section{Fault textures in obsidian}

Four textural classes of faults have been identified, which correspond to four phases of fault evolution within rising magma, and represent a single, complete fault cycle.

Phase 1 : Formation of initial fracture networks

Description: The obsidian zones of both conduits are cut by anastomosing networks of fractures (Figure 3), ranging from a few centimetres to 4.8 metres in length. Fractures are bounded by irregular, embayed and locally planar obsidian surfaces, and following the nomenclature of Curewitz and Karson (1999), can be divided into three types on the basis of their morphologies: fault veins (mode I fractures), injection veins (mode II fractures) and reservoir zones (Figure 3). Fault veins are typically 1-20 mm thick, nearly planar, and have measurable thrust or normal displacements of $<1$ to $130 \mathrm{~mm}$. Injection veins are 0.01 to $>1 \mathrm{~m}$ long tensional fractures with no measurable shear displacement, apertures of 1-10 mm, and occur in the walls of fault veins (Figure 3a,c). There is commonly a slight mismatch between opposite walls of veins, indicating abrasive wear during opening (e.g. Curewitz and Karson 1999). Reservoir zones are larger, irregular voids up to $80 \mathrm{~mm}$ in width, and are always linked to fault veins. Fracture surfaces cut across phenocrysts and earlier flow structures in the obsidian. The largest fracture network seen, in the western obsidian wall of Thumall Conduit, comprises complex fault veins, multiple injection veins and numerous reservoir zones, and has a total length in excess of $4.8 \mathrm{~m}$. The maximum measured displacement on its fault veins is $130 \mathrm{~mm}$. All three fracture types are filled by pale- to mid-grey fine-grained, banded material that consists of angular glassy clasts and phenocryst fragments, and exhibits conchoidal fracture. Bands are between $\sim 0.2$ and $20 \mathrm{~mm}$ thick and laterally continuous over millimetres to tens of centimetres (Figure 3b); most are nearly parallel to the walls of fault veins and injection veins, but display complex cross bedding in reservoir zones. 
Fault textures in volcanic conduits

Bands vary in sorting and grain size; the palest bands are well-sorted with angular clasts 10-100 $\mu \mathrm{m}$ across, whereas darker bands are commonly poorly-sorted and contain rounded clasts of obsidian up to $10 \mathrm{~mm}$ across. Individual bands can be traced from fault veins into injection veins, where their thicknesses slightly decrease, and into reservoir zones (Figure 3b), where thicknesses commonly greatly increase.

The three-dimensional arrangement of fractures is complex, and no preferred orientation of fractures or offset directions was obvious from the geometry of the exposures. At Thumall Conduit, the density of fractures is greatest in the obsidian zones, and no fractures were observed in the central devitrified rhyolite. By contrast, fractures were observed in all textural zones of Skriðugil Conduit, including the vesicular Figure 3 material in the conduit centre.

Interpretation: The fractures were formed by shear failure of deforming highly viscous magma within the glass transition interval, when shear stress exceeded the shear strength of the magma during unrelaxed deformation (Tuffen et al. 2002b, 2003).

Unrelaxed deformation of silicate melts occurs when $\varepsilon^{\prime} \eta>10^{8} \mathrm{~Pa}$, where $\varepsilon^{\prime}$ is the shear strain rate and $\eta$ the shear viscosity (Webb and Dingwell 1990). As the viscosity of magma in the glass transition interval falls in the range $10^{9}-10^{14} \mathrm{~Pa}$ s (Gottsmann et al. 2002), the strain rates must have been in the range $10^{-2}$ to $10^{-6} \mathrm{~s}^{-} 1$ for unrelaxed deformation to occur (Tuffen et al. 2003). Such strain rates are typical of effusive eruptions of silicic magma, and were most probably caused by viscous coupling between highly-viscous magma close to the conduit walls and less-viscous magma rising in the centre of conduit (Tuffen et al. 2002b, 2003). The absence of fractures in the centre of Thumall Conduit suggests that only relaxed deformation occurred in this location, due to either a lower strain rate or lower viscosity. Injection veins were probably formed by tensile fracture of fault vein walls during slip, although fluid pressure may have also played a role. 
Fault textures in volcanic conduits

The geometry and scale of fracture networks, the relationship between fault veins, injection veins and reservoir zones, and the characteristics of the fracture-filling material is almost identical to those in pseudotachylite fault rocks formed during shallow tectonic faulting of the east Greenland volcanic rifted margin (Curewitz and Karson 1999) and on the Iida-Matsukawa fault within granitic cataclasite in central Japan (Lin 1996). We propose that the fine-grained particles in phase 1 fractures were generated by abrasive wear during fracturing and frictional sliding, and spalling from the walls of extensional microfractures. These are mechanisms active during pseudotachylite formation (Lin 1996; Curewitz and Karson 1999). The absence of both fragmented counterparts (i.e. matching fragments of a larger parent clast) and zones of localised deformation structures suggests that the particles were fluidised (i.e. loosely packed particles were able to move with a mean free path, Monzawa and Otsuki 2003). Bands are thus interpreted as sedimentary structures formed by gas transport of particles through the fracture system, as indicated by the continuity of bands between fault veins, where particles were generated, and reservoir zones, where particles accumulated (Sibson 1975; Curewitz and Karson 1999). The roundness of some large clasts suggests that frictional melting and/or particle abrasion also occurred during slip (Lin 1999).

Similar fine-grained material also has been observed in the upper carapaces of rhyolitic lava flows (Manley 1996; Allen and McPhie 2003), and formed "from comminution of solid lava adjacent to fractures that later healed" (Allen and McPhie, 2003). Although we suggest that similar fracture-healing processes occur in shallow conduits to those in lava flows and domes, the mechanism of redistribution of particles was different. The morphology of some beds within phase 1 fractures indicates that flow was upward, and therefore probably controlled by transient pressure differentials during fracture, rather than gravity (c.f. Manley 1996). The fracture-filling material can be considered to be an intrusive pyroclastic deposit (Heiken et al. 1988; Lin 1996), the gas 
phase being derived from exsolved magmatic volatiles in vesicles and other pore space intersected by the fracture (see also Smith et al. 2001). The pressure gradient required to drive flow of the fluidised gas-particle mixture was created when tensional cavities opened in the fracture system and formed transitory low-pressure zones (Lin 1996; Curewitz and Karson 1999), a process that can occur at depths of several kilometres during seismic faulting (Sibson 1986). The variations in the grainsize and sorting of fracture-filling material in different beds are thought to indicate fluctuations in the gasparticle ratio, current velocity, and degree of fluidisation during deposition (e.g. Branney and Kokelaar 1992). Similar beds of fine-grained glassy particles and broken crystals occur within tuffisite veins in the walls of the Mule Creek conduit, New Mexico, and are thought to indicate fluctuating flow of magmatic volatiles through a short-lived fracture system (Stasiuk et al. 1996). This process may assist gas loss through conduit walls during explosive eruptions, and encourage the transition to effusive activity (Stasiuk et al. 1996; Jaupart 1998). As discussed below, the fluidisation of a gas-particle mixture within a fracture network, as recorded in these textures, is a plausible mechanism for the generation of low-frequency seismic events during volcanic eruptions (Kumagai and Chouet 2000).

Phase 2 : Slip on cataclasite shear zones

Description: Complex, branching zones of pale-to mid-grey glassy cataclasite centimetres to $>3 \mathrm{~m}$ in length occur in the obsidian of both conduits. Most shear zones are nearly vertical and range from $<1 \mathrm{~mm}$ to $50 \mathrm{~mm}$ in thickness. They are bounded by obsidian surfaces, which are mostly near-planar, but locally highly embayed and irregular. The bulk of the cataclasite occurs in mid-grey bands that are 1-10 mm thick and laterally continuous over centimetres or tens of centimetres, consisting of angular to partly-rounded glassy clasts and angular phenocryst fragments $0.1-5 \mathrm{~mm}$ across. 
Fault textures in volcanic conduits

Complex internal structures are visible in thin section (Figure 4), each zone consisting of bands with varying colour and grain size (Figure 4a). The cataclasite is subtly foliated, due to clast alignment. Elsewhere in the cataclasite, trails of angular clasts are commonly observed adjacent to larger clasts, while other larger clasts are cut by small fractures (Figure $4 \mathrm{a}$ ) and have mosaic microstructures. The surfaces of clasts are coated by numerous euhedral, 1-10 $\mu$ m metallic oxide crystals. Phenocrysts commonly protrude from the surrounding obsidian surfaces into the cataclasite shear zones, and bands in the cataclasite zone are deflected around the crystals (Figure 4a). Pale grey ultracataclasite bands $<1 \mathrm{~mm}$ thick commonly occur at the contact with the surrounding obsidian, and can be traced laterally over tens of centimetres. They appear as pale grey bands in outcrop and dark bands in thin section (Figure 4), Ultracataclasite clasts are similar to those in the coarser-grained cataclasite, but grain sizes are 10-100 $\mu \mathrm{m}$. Ultracataclasite bands 1-3 mm wide also occur as Riedel shear zones, cutting cataclasite bands at oblique angles (Figure $4 \mathrm{~b}, \mathrm{c})$. Some such bands are deflected around the margins of individual clasts within the surrounding cataclasite (Figure 4c). Up to three distinct, cross-cutting foliations are visible in thin section (Figure 4c), indicating a complex, multi-stage deformation history.

Figure 4

Interpretation: The microtextures in the cataclasite shear zones closely resemble those in ultracataclasites, cataclasites and angular pseudotachylites that occur on seismogenic tectonic faults (e.g. Chester and Chester 1998; Curewitz and Carson 1999; Monzawa and Otsuki 2003). Although involvement of fluidised clastic transport in creating the bands of distinct grain size (the mechanism active during phase 1) cannot be ruled out everywhere, there is strong evidence for localised grain size reduction on Riedel shear zones, in the presence of mosaic microstructures and microfractures within clasts (Monzawa and Otsuki 2003). These are textures characteristic of seismogenic, frictioncontrolled slip (Chester and Chester 1998; Monzawa and Otsuki 2003). Similar textures 
Fault textures in volcanic conduits

have been created in frictional stick-slip experiments in simulated fault gouge (e.g. Byerlee 1978; Marone and Scholz 1989). However, there is also evidence for homogeneous shear deformation, together with compaction and clast imbrication. Such textures may be indicative of aseismic stable sliding (e.g. Monzawa and Otsuki 2003). Therefore, taken together, textures in the cataclasite shear zones are thought to signify seismogenic slip events interspersed with periods of aseismic frictional sliding (creepslip behaviour, Beeler et al. 2001). Laboratory friction experiments have shown that the transition from stick-slip to stable sliding is principally controlled by the shear strain rate and temperature (e.g. Shimamoto 1986; Scholz 1998). Partial sintering of clast-clast contacts within the cataclasite is an indicator of frictional heating (Curewitz and Karson 1999), which suggests that frictional heating may have played a role in modifying the slip behaviour.

The dimensions, branching nature and embayed walls of cataclasite shear zones indicate that they were derived by progressive shear and rotation of the angular fracture zones of phase 1. Indeed, there is a morphological continuum between the angular, undeformed fracture networks and rotated cataclasite shear zones, with a progressive process of coalescence, rotation of fault branches and abrasive wear gradually converting initial fractures into mature shear zones (Vermilye and Scholz 1998; Curewitz and Karson 1999; Ben Zion and Sammis 2003)

Although shear was clearly friction-controlled and deformation purely brittle, the deflection of ultracataclasite Riedel shear zones around clasts in the cataclasite indicates that parts of the cataclasite had become cohesive whilst others underwent fluidisation during localised slip (Chester and Chester 1998). Cohesion (where particle-particle interfaces become bonded) was attained through comminution, rotation and close packing during shear deformation (Monzawa and Otsuki 2003), together, locally, with the onset of sintering. Deflection of ultracataclasite around existing clasts also indicates 
Fault textures in volcanic conduits

that the fine-grained material was not formed by in-situ cataclasis; it must instead have been generated elsewhere and then transported to fill in the voids between clasts in cohesive cataclasite. This transport is most likely to have occurred in a fluidised state. Therefore, although there is clear evidence for localised deformation controlled by grain friction and crushing by contact stresses, there may also evidence for the transition to a fluidised state, which requires a small decrease in the volume fraction of particles, possibly caused by slight dilation of the fault zone (Monzawa and Otsuki 2003).

Phase 3 : Ductile deformation of cataclasite zones

Description: Deformed cataclasite zones are pale- to mid- grey, mostly near-vertical but occasionally branching and irregular, and commonly folded and tightly crenulated (Figure 5). They are the most common textural group, and occur throughout the obsidian of both conduits. Deformed cataclasite zones often occur as complex groups of bands, some of which are almost planar, whereas others have single-layer recumbent isoclinal, disharmonic and ptygmatic folds (Castro and Cashman 1999) with wavelengths of $<0.5$ $\mathrm{mm}$ to $>20 \mathrm{~cm}$ (Figure 5b,d). The most-deformed bands have undergone shortening (initial/final length) of $>2$, and the orientation of fold axes is highly variable. Deformed zones vary between tens of centimetres and $>3 \mathrm{~m}$ in length and $<1 \mathrm{~mm}$ to $50 \mathrm{~mm}$ in thickness, exhibit conchoidal fracture, and are distinctive in handspecimen and outcrop for their paucity of intact phenocrysts. They comprise bands of mid-grey cataclasite and pale-grey glassy ultracataclasite with similar thicknesses, grain sizes, and lateral continuity to phase 2 bands, but sintering and elongation of glassy clasts by viscous shear parallel to the margins of the zone has produced a distinct foliation (Figure 5c). Other deformed cataclasite zones more closely resemble crenulated initial fracture networks (Figure 5a), and original sedimentary textures in reservoir zones and injection veins can still be discerned. Viscous shear is most pronounced in the largest glassy 
Fault textures in volcanic conduits

clasts within cataclasite bands (Figure 5c), where axial strain may exceed 10, whereas the smallest clasts in the ultracataclasite are almost undeformed. Locally, subtle millimetre-scale crenulations and kink bands in the cataclasite pass through adjacent clasts (Tuffen et al. 2003, Figure 2d). None of the clasts within the cataclasite exhibit mosaic microstructures, and individual cataclasite bands are deflected around crystals. In thin section, viscous deformation of clasts is seen to be parallel to the margins of the folds, rather than the fold axes (Figure 5c). Surfaces of clasts within the cataclasite are covered by abundant microlites of metallic oxides, which are mostly 1-10 $\mu \mathrm{m}$ across and do not occur within the clasts.

At the western edge of the obsidian zone of Thumall Conduit, obsidian containing deformed cataclasite bands grades into spherulitic, devitrified rhyolite. Cataclasite bands are parallel to and have similar widths to bands of spherulitic growth, although it is not clear whether spherulites preferentially form on cataclasite bands.

Figure 5

Interpretation: The viscous deformation of individual clasts parallel to the band orientations, absence of evidence for in-situ fracturing of clasts, and continuity of ductile folding through adjacent clasts all indicate that deformation of the cataclasite was cohesive, with shear resistance governed by viscosity rather than friction (e.g. Shimamoto 1986). This phase represents the onset of ductile deformation, which greatly modified the textures in cataclasite formed by earlier brittle deformation (Stel 1986; Takagi et al. 2000) and corresponds to the rounded pseudotachylite lithology of Curewitz and Karson (1999). The transition from friction-controlled slip to cohesive viscous deformation marks the end of the seismogenic phase, as there is no evidence for fluidisation or fracturing at this stage.

The onset of viscous deformation, through thorough sintering of particles, may be due to decreased strain rate (Shimamoto 1986), increased temperature (Curewitz and Karson 1999), or both. In microstructural terms, cohesion is attained when particle- 
Fault textures in volcanic conduits

particle contacts are sufficiently sintered to no longer be planes of weakness. Since annealing is time-dependent (e.g. Dietrich 1979; Marone 1998; Scholz 1998; Quane and Russell 2003), cohesive deformation is favoured by slow strain rates, at which the hold time of adjacent surfaces is sufficient for complete restrengthening of particle-particle contacts. This allows deformation to be governed by the shear viscosity of the "bulk" material. At higher strain rates, the hold time is insufficient for complete annealing, the particle-particle contact surfaces remain as weak points in the deforming material, and frictional sliding on particle contacts provides the resistance to shear (Shimamoto 1986; Scholz 1998). The transition from phase 2 to phase 3 may therefore reflect a decrease in strain rate.

The rate of annealing of adjacent particles is also sensitive to temperature. Viewed simply, "stable" sliding (e.g. cohesive viscous deformation) which occurs in granites above $300{ }^{\circ} \mathrm{C}$ due to ductile deformation of quartz crystals (Stesky et al. 1974; Scholz 1998), requires cohesion between particles (or crystals, or grains). Sintering is greatly accelerated at higher temperatures and lower viscosities (Quane and Russell 2003; Tuffen et al. 2003), and thorough sintering was achieved in silica-quartz powder at 727$1027{ }^{\circ} \mathrm{C}$ over a timescale of $<13$ hours (Luan and Patterson 1992). Therefore, at a constant strain rate, a sustained increase in temperature can bring about the transition from frictional to viscosity-controlled deformation. Since the viscosity of magma in the glass transition is extremely sensitive to temperature (Gottsmann et al. 2002), the role of frictional heating may be important in governing this behavioural transition during faulting in magma. For example, if the temperature of a rhyolitic melt were to increase from 600 to $612{ }^{\circ} \mathrm{C}$ during frictional slip, a very modest temperature increase during frictional slip (O’Hara 2001), its viscosity would decrease by more than a factor of two (Gottsmann et al. 2002). 
Fault textures in volcanic conduits

The temperature increase within the deforming zone depends upon the proportion of heat generated by viscous dissipation that is retained (Hobbs et al. 1986, O'Hara 2001) and is greater during continuous sliding than during stick-slip behaviour (Brown 1998). Therefore, once annealing occurs during the onset of cohesive viscous deformation, deformation is unlikely to return to a frictional cataclastic mode, as heating of the deforming material becomes more efficient, albeit more dispersed. The geometry of folds, where deformed cataclasite zones are interlayered with "intact" obsidian, indicates that the layer had similar viscosity (Castro and Cashman 1999).

The fault can be considered healed once ductile deformation becomes dominant and the viscosity of the cataclasite becomes similar to the surrounding material, so that localised slip can no longer occur, and conditions for the reactivation of the fault no longer exist. New phase 1 fractures cut through phase 3 cataclasite (Figure $7 b, c)$, indicating that the earlier faults had completely healed and restrengthened (Tuffen et al. 2003).

From the perspective of melt physics, the transition between phases 2 and 3 equates to passing from the glass transition into the liquid field (Dingwell and Webb 1989), due to either a decrease in the strain rate or viscosity. Enrichment in metallic oxides, as observed in this phase, has been documented in many pseudotachylites that have undergone frictional melting (e.g. Curewitz and Karson 1999), providing further evidence for frictional heating of the magma to above the glass transition.

Crystallisation of oxide minerals on glassy particle surfaces occurs during experimental heating of silicate melts to just above the glass transition temperature (MJ Toplis, pers. comm. 2003).

Phase 4 : Formation of flow banding from healed cataclasite 
Fault textures in volcanic conduits

A variety of microtextures in highly-deformed cataclasite zones indicates progressive healing and modification of the textures formed during brittle phases 1-2, illustrating a process that generates millimetre-wide microlite-rich bands in obsidian. Although there is a broad spectrum of textures within this phase, it has been divided into three stages, each of which is described below. This lithology is broadly similar to the glassy pseudotachylite described by Curewitz and Karson (1999).

\section{Figure 6}

Description: The boundaries between glassy clasts within some deformed cataclasite zones of phase 3 only can be detected by the abundance of metallic oxide microlites on the relict clast surfaces (phase 4a, Fig. 6a,b). Otherwise, the glass colour is identical, and clasts have undergone high axial shear strain, with $\Delta \mathrm{L} / \mathrm{L}$ above 10 in clasts over 0.25 $\mathrm{mm}$ in length, and are commonly crenulated (Figure 6a). Such deformed cataclasite zones are made up of several bands of distinct colour commonly 0.05-0.2 mm across. Different band colours reflect different clast sizes; the bands containing the smallest clasts are darkest in colour, because the number density of metal oxide microlites is highest. The arrangement of bands is similar to phase 2 and phase 3 cataclasite, with darkest bands commonly occurring at the contact with the surrounding obsidian. Furthermore, the sizes and relative abundance of crystal fragments and glassy clasts are the same as in phase 2 and 3 cataclasite. Although phase 4a zones appear, in general, to have undergone higher shear than phase 3 zones, there is no clear spatial separation between the two textural classes, which are commonly observed together within a single thin section.

Some highly-deformed cataclasite zones occur as compound bands of variablycoloured obsidian containing randomly-orientated microlites and phenocryst fragments (phase 4b, Fig. 6c-e). As in phase 4a, the band colour reflects a range of microlite number densities (Figure 6e), but the outline of individual clasts cannot be traced. The 
Fault textures in volcanic conduits

banding generated in phases 1 and 2 is preserved, and in general, the darkest bands, corresponding to ultracataclasite in phase 2 , are mostly found immediately adjacent to the surrounding obsidian. Phase $4 \mathrm{~b}$ zones are commonly $0.1-5 \mathrm{~m}$ in length and $0.2-20$ $\mathrm{mm}$ thick, and are often closely associated with less-developed bands of phases 3 and $4 \mathrm{a}$ (Figure 6c, 7b). Bands are deflected around phenocrysts (Figure 6c,d), and, where folded, appear to have had similar viscosities to the surrounding microlite-poor melt. Numerous bands have undergone a further stage of deformation (phase 4c) that has completely rearranged the microlites and destroyed all internal structures. These bands are tens of centimetres or metres in length, mostly near-vertically orientated and almost indistinguishable in outcrop and handspecimen. The bands are commonly folded or crenulated and are deflected around phenocrysts (Figure 6f).

Interpretation: Textural similarities indicate that phase $4 \mathrm{a}$ bands are derived from progressive ductile deformation and healing of phase 2 and 3 cataclasite zones, in a similar way to the conversion of angular to glassy pseudotachylite (Curewitz and Karson 1999). Thorough sintering of particle-particle contacts has occurred during cohesive ductile deformation so that only the presence of microlites on former clast surfaces preserves evidence for the earlier clastic phases. Westrich and Eichelberger (1994) have also found that annealing of magma can entirely obliterate earlier textures, and Rust et al. (2003) describe similar textures in annealed pyroclastic obsidian, where the distribution of lithic fragments, irregular vesicles and microlites indicate the position of earlier clast boundaries. Although the process of clast boundary destruction during annealing is important in volcanology, as a controlling factor on welding of pyroclastic deposits (Sparks et al. 1999; Gottsmann and Dingwell 2002), it is poorly understood. Tuffen et al. (2003) suggested that such annealing is relaxation-related and occurs on a timescale similar to the relaxation timescale. Indeed, ductile deformation indicates that 
Fault textures in volcanic conduits

the magma was in the liquid field, where the relaxation timescale is less than the deformation timescale (Dingwell and Webb 1989; Dingwell 1996, 1997), and aseismic viscosity-controlled slip was occurring.

Microlites in phase $4 \mathrm{~b}$ zones have become reorganised during ductile deformation, so that there is no evidence for former clasts. If this textural zone were observed alone and out of context, it would be impossible to deduce that it were derived from annealed cataclasite. However, the preservation of banding structures equivalent to those in phases $2-4 a$, along with the similar crystal contents, zone dimensions, and close relationships between zones in outcrop, clearly indicates that phase $4 \mathrm{~b}$ zones were generated by progressive ductile deformation of phase 2-4a zones. Reorganisation of microlites probably occurred during distributed ductile shear of phase $4 \mathrm{a}$ zones.

In phase $4 c$, ductile shear has mingled bands of varying microlite number density within zone $4 \mathrm{~b}$ and destroyed the banding textures first generated in phase 2 . Microliterich bands of this type are near-ubiquitous in the obsidian of silicic lava flows (e.g. Vernon 1987; Castro and Cashman 1999; Smith 2002), and all evidence for their formation in the conduit has been obliterated by subsequent deformation. We hypothesize that microlite-rich flow bands in obsidian may represent healed cataclasite fault zones, and can be considered to be fossils of the earthquakes that occurred during mixed brittle-ductile flow of viscous magma within the conduit (Tuffen et al. 2003). If it can be established that melting, rather than relaxation, occurred during phases 3 and 4 , such flow bands should be considered to be glassy pseudotachylite (Curewitz and Karson 1999). The fact that this type of flow banding is restricted to silicic glasses (basaltic glass does not contain microlite-rich flow bands) suggests that the flow-bandgenerating process described above (phases 1-4) can only occur in silicic melt compositions. The conditions required for the process - prolonged residence of melt- 
Fault textures in volcanic conduits

bearing magma in the glass transition interval - cannot be met by basic magmas, which crystallise too rapidly (Tuffen et al. 2003).

Figure 7 Repeated phases: cyclic brittle-ductile deformation

Deformed cataclasite of phases 3-4 is cut by new phase 1 fractures throughout the obsidian of both conduits (Figure 8). The orientation of new fractures is unrelated to the geometry of existing bands that act as displacement markers (Figure 8a,b), and the cataclasite formed on new generations of fractures contains clasts of older deformed cataclasite. No new fractures were observed cutting phase 2 cataclasite. These relationships indicate that magma had thoroughly healed during ductile deformation in phases 3-4, and former zones of brittle deformation could no longer be exploited for localised slip. The textures indicate that the magma underwent multiple cycles of brittleductile behaviour, and thus had a prolonged residence in the glass transition interval (Tuffen et al. 2003). Brittle-ductile textures in the Unzen lava dome also indicate that more crystalline magma may undergo mixed deformation within the glass transition (Smith et al. 2001).

Cross-cutting fault textures, indicating cyclic brittle-ductile behaviour, can be explained by variations in strain rate and temperature. At constant strain rate, cooling of initially ductile magma by heat loss into country rock may increase viscosity sufficiently to trigger brittle behaviour (Figure 9a) (i.e. cooling through the glass transition, Dingwell 1996). The strain rate and temperature then both increase during localised frictional slip. An increase in cohesion during frictional heating eventually leads to distributed deformation, greatly reducing the strain rate, and the heating magma then crosses back above the glass transition, allowing a return to ductile deformation. Upon continued cooling, magma may again cross the glass transition and deform in a brittle 
Fault textures in volcanic conduits

fashion. At constant temperature, brittle-ductile cycles may be triggered by a pulsatory strain rate (Figure 9b), with brittle behaviour triggered by high strain rate pulses that are superimposed onto a low "background" strain rate. Similar models are used to explain mixed brittle-ductile deformation textures in lower-crustal rocks, which contain coexisting mylonitic and cataclastic textures (Stel 1986; Gratier et al. 1999; Fabbri et al. 2000; Takagi et al. 2000). High strain-rate pulses in the lower crust are thought to occur when a seismogenic rupture has propagated into an otherwise ductile regime. Since strain rate and temperature are intrinsically coupled during viscous conduit flow (Mastin 2002; submitted manuscript), both parameters are likely to have varied together during cyclic brittle-ductile deformation (Figure 9).

\section{Figure 8}

Figure 9

\section{Faulting mechanisms and their relation to volcano seismicity}

The textures described above provide evidence for cycles of seismogenic faulting within a shallow magma-filled conduit. In this section we examine how the faulting process recorded in the Icelandic conduits is consistent with many of the characteristics of LP and hybrid events during lava dome eruptions.

The initial fracture event (phase 1) involves the dynamic rupture of viscous magma and the generation of an angular network of fractures. Sedimentary structures in the fine-grained material formed during fracture events indicates fluidisation of a gasparticle mixture within the fractures, implying that transient pressure gradients existed during and just after the rupture (Lin 1996; Curewitz and Karson 1999). Reduction of normal stress in all or part of the fracture wall may then trigger resonance either of the newly-formed fracture system (Chouet 1988) or the entire conduit (Neuberg 2000). The absence of S-wave arrivals in hybrid earthquakes (White et al. 1998; Neuberg 2000) is 
Fault textures in volcanic conduits

consistent with a source within flowing magma, rather than solidified rock. The grain size of particles formed during the initial fracture event is consistent with the sizes of grains required by ash-filled crack resonance models to produce the quality factors measured for LP events (Kumagai and Chouet 2000). The aperture of the fracture zones in the Icelandic conduit closely match the aperture of cracks inferred as resonators during LP seismicity at the Galeras lava dome (Gil Cruz and Chouet 1997). However, the lengths and widths are more than one order of magnitude smaller than those required for crack resonance models (Gil Cruz and Chouet 1997; Kumagai and Chouet 2000). Conduits active during recent lava dome eruptions typically have radii of 15-30 m (Goto 1999; Voight et al. 1999; Hammer et al. 2000), up to five times those of the Icelandic conduits, while fractures in the walls of the Mule Creek conduit, New Mexico are up to $25 \mathrm{~m}$ in length (Stasiuk et al. 1996), five times greater than the largest observed fracture in Iceland. This mismatch may simply be due to the different sizes of conduits. Alternatively, gas released from fractures may flow into and resonate a larger, preexisting crack in the country rock or dome (Gil Cruz and Chouet 1997).

The initial fracture is thought to be triggered by accumulation of shear stress in highly-viscous magma undergoing unrelaxed deformation (Goto 1999; Tuffen et al 2003). The shear stresses are caused by the pressure gradient in the conduit and by viscous coupling with the conduit margins (Tuffen et al. 2002b; Gonnerman and Manga 2003). In this way, the fracture of magma at conduit margins is analogous to the fracture of the brittle, chilled crust of a lava flow or dome by shear stresses in the interior.

Magma in the conduit may attain the high viscosity necessary for unrelaxed deformation by conductive cooling into the country rock, crystallisation and degassing. The position in the conduit where fracture occurs is determined by the spatial distribution of viscosity and strain rate. Fracture may be favoured by a constriction in the conduit, which leads to increased strain rates, a region of high heat or gas loss through the conduit walls (Tuffen 
Fault textures in volcanic conduits

et al. 2003), or in an upward-flaring section of the conduit where normal stress at the walls is low. These ideas are consistent with those of Uchida and Sakai (2002), who have proposed that hybrid earthquakes at Satsuma-Iwojima lava dome are triggered by shear fracture events within the magma. Their interpretation is based on particle motions derived from multiple seismometers and the low frequency content of the earthquakes, which is attributed to slow fracture of viscous magma (Uchida and Sakai 2002). Neuberg et al. (2003) have also invoked a shear fracture trigger model for repetitive low-frequency seismic events at the Soufriere Hills lava dome, Montserrat.

The magnitude of seismic signal generated by the fracture events in the two conduits can be roughly estimated from the dimensions and displacement of fractures (Tuffen et al. 2003), although it is not possible to estimate the degree of subsequent signal amplification by resonance. The seismic moment $\mathrm{M}_{\mathrm{o}}$ is given by DGA, where $\mathrm{D}$ is mean displacement, $\mathrm{G}$ is the shear modulus (assumed to be $\sim 10^{10} \mathrm{~Pa}$ ) and $\mathrm{A}$ the fault area. Taking values of $\mathrm{D}=0.13 \mathrm{~m}$ and $\mathrm{A}=25 \mathrm{~m}^{2}$ from the largest observed fracture network and using the equation for moment magnitude $M_{w}=2 / 3 \log M_{o}-10.7$ gives a moment magnitude of 0.3 , which is similar to recorded LP and hybrid earthquake magnitudes (e.g. Gil Cruz and Chouet 1997; Miller et al. 1998, Uchida and Sakai 2002; Umakoshi et al. 2002).

Field evidence suggests that repeated seismogenic faulting occurred on each fault zone, and then died out as the fault healed and a new fault developed. Each fault zone probably triggered a group, or swarm of earthquakes, rather than a single event (c.f. Tuffen et al. 2003). Since each slip event modified the cataclasite on the fault plane (e.g. wear, grain size reduction), successive seismic signals are likely to have been subtly different. This evidence fits closely with the interpretation of seismic data from Unzen volcano, Japan during a period of dome growth between November 1993 and September 1994 (Umakoshi et al. 2002, 2003). Hybrid events were divided into groups by cross- 
Fault textures in volcanic conduits

correlation, and subtle changes in the waveforms were detected during each swarm.

Umakoshi et al. suggested that each group corresponded to movement on a certain fault plane (or shear zone), and at any one time between 2 and $\sim 20$ groups were active. The beginning and end of individual swarms correlated to changes in the surface growth of the lava dome. We suggest that the textures preserved in the Icelandic conduit record the birth and death of faults, or shear zones, of the type that Umakoshi has suggested.

Three alternative models can explain the end of seismic stick-slip activity and onset of aseismic distributed deformation, which may correspond to the end of an earthquake swarm: decreasing strain rate, increasing temperature, and close packing of cataclasite during slip, which prevents fluidisation (Monzawa and Otsuki 2003). In the first model, seismic-aseismic deformation is simply controlled by high strain rate pulses superimposed on a lower background rate (Takagi et al. 2000), with earthquakes being generated in sudden slip events. Hidayat et al. (2000) considered stick-slip motion of magma as a trigger mechanism for multiphase seismic events at Merapi volcano, Java, and showed that the magma rise rate could be accommodated by one seismogenic slip event of $0.2 \mathrm{~mm}$ every 4 seconds. This stick-slip model assumes that slip events involve piston-like slip of the entire inner conduit against its static walls (Denlinger and Hoblitt 1999). However, the fault zone geometries described in this paper show that slip may be accommodated by movement on numerous localised, ephemeral fault zones within the mixed brittle-ductile boundary layer between the rigid conduit walls and fluid centre. Indeed, Umakoshi et al. $(2002,2003)$ show that many fault zones may be active within a conduit at any one time.

The second model requires frictional and viscous heating to trigger sintering of particles, and then sufficiently reduce magma viscosity for deformation to become ductile. Luan and Patterson (1992) showed that sintering of silica-quartz powder may take up to 13 hours, depending on temperature and confining stress, whereas LP and 
Fault textures in volcanic conduits

hybrid swarms may last hours or weeks. Although these timescales appear to be similar, further work is required to determine the effects of temperature, loading, crystallinity and melt composition on the rate of sintering.

Progressively closer packing of cataclasite during slip, comminution and wear may also prevent fluidisation, encourage distributed deformation, and make a fault aseismic (Monzawa and Otsuki 2003). Since the volume percentage of particles within the fault zone increased from phase 1, when deposition from a fluidised gas-particle mixture occurred, to phase 2 and 3, when little or no pore space was present, this process is likely to have occurred at some stage during the deformation cycle. Once deformation becomes distributed, the strain rates are greatly reduced, favouring aseismic behaviour. Some intriguing new seismic data are consistent with this model. Molina et al. (2004) have found that systematic changes in the quality factor of LP events during a swarm at Tungarahua volcano, Ecuador, can be explained by an increase in the volume fraction of particles within a resonant crack, using the model of Kumagai and Chouet (2000). Once the volume fraction exceeded $\sim 65 \%$, the proportion required for close packing, the swarm abruptly stopped. This pattern of seismicity could be understood in terms of a fault zone maturing from phase 1 to phase 3 , with particles derived from abrasion progressively filling the fault zone.

On a simplistic level, the repeat time of seismic slip events on fault zones in magma may be expected to be determined by the frictional properties of the cataclasite, the strain rate and normal loading. However, the exact timing also may be strongly influenced by complex interactions between fault systems and remote triggering of seismic events, which is a well-established phenomenon elsewhere in the crust (e.g. Hill et al. 1993). Whereas faulting in viscous magma may be considered to be the onset of fragmentation, dome collapse or runaway fracturing is not an inevitable consequence of an initial fracture (Gonnerman and Manga, 2003). Dome instability may occur if faults 
Fault textures in volcanic conduits

propagate into high-viscosity magma, such as the cooled upper part of a lava dome, which is in the unstable (velocity weakening) frictional regime (Scholz 1998). The next challenge is to relate the frequency characteristics of LP and hybrid events and their repeat times to the physical state of the magma undergoing seismic slip in the conduit (e.g. viscosity, temperature, crystallinity, vesicularity, confining pressure). In particular, criteria need to be developed to determine whether seismic events are generated in wall rock or magma (possibly VT events as opposed to LP and hybrid events). Better understanding of the relative roles of friction- and viscosity-controlled deformation within conduits with strong lateral and vertical temperature gradients is required, along with further experimentation to extend the determination of frictional properties (Blanpied et al. 1995) and sintering processes of magma (Quane and Russell 2003) to a range of compositions, temperatures and crystallinities relevant to lava dome eruptions. Another aspect of faulting in magma that will be addressed elsewhere is that it creates spatial and temporal variations in conduit permeability, which may have an important influence on degassing behaviour. Together such investigations would improve our understanding of how patterns of shallow seismicity relate to the state of the magmafilled conduit, and the likelihood of sudden, potentially catastrophic changes in activity.

\section{Conclusions}

Numerous small-scale seismogenic fault zones were active within highly viscous magma rising at a shallow level in volcanic conduits. They were initiated by flowinduced shear fracture, before coalescing and entering a phase of friction-controlled stick-slip behaviour. Sintering of cohesive cataclasite led to distributed ductile deformation and ended the seismogenic phase; continued ductile deformation then formed microlite-rich flow bands in obsidian. This process was repeated, and led to 
Fault textures in volcanic conduits

complex brittle-ductile textural associations, similar to those formed at the base of the crust. Textures suggest that seismogenic faulting within silicic magma is likely to be friction-controlled, with the lifetime of faults governed by the interplay between strain rate, frictional heating and shear viscosity. Fault characteristics are consistent with existing volcano seismic trigger models and seismic data from active lava domes. Future models of volcano seismicity should consider incorporating the rate- and statedependent frictional laws and dynamic rupture models that have only been used, to date, in the study of seismicity elsewhere in the crust.

\section{Acknowledgements}

Many thanks to Susan Sturton, Yehuda Ben Zion, Jürgen Neuberg, Jacopo Taddeucci, Emily Brodsky and Ron Vernon for interesting discussions. The paper was much improved by thoughtful reviews from Larry Mastin, John Stix and Hiroyuki Kumagai. HT was funded by an Alexander von Humboldt Fellowship and the Cumberland Geological Society.

\section{References cited}

Allen SR, McPhie J (2003) Phenocryst fragments in rhyolitic lavas and lava domes. J Volcanol Geotherm Res $126: 263-283$

Ben-Zion Y (2001) Dynamic ruptures in recent models of earthquake faults. J Mechan Phys Solids 49:22092244

Ben-Zion Y, Sammis CG (2003) Characterization of fault zones. Pure Appl Geophys 160:677-715

Blanpied ML, Lockner DA, Byerlee JD (1995) Frictional slip of granite at hydrothermal conditions. J Geophys Res 100:13045-13064

Beeler NM, Lockner DL, Hickman SH (2001) A simple stick-slip and creep-slip model for repeating earthquakes and its implication for microearthquakes at Parkfield. Bull Seis Soc Am 91:1797-1804

Branney MJ, Kokelaar P (1992) A reappraisal of ignimbrite emplacement - progressive aggradation and changes from particulate to nonparticulate flow during emplacement of high-grade ignimbrite. Bull Volcanol 54:504-520

Brown SR (1998) Frictional heating on faults: Stable sliding versus stick slip. J Geophys Res 103:7413-7420

Byerlee J, Mjachkin V, Summers R, Voevoda O (1978) Structures developed in fault gouge during stable sliding and stick-slip. Tectonophysics 44:161-171

Castro J, Cashman KV (1999) Constraints on rheology of obsidian lavas based on mesoscopic folds. J Struct Geol 21:807-819 


\section{Fault textures in volcanic conduits}

Chester FM, Chester JS (1998) Ultracataclasite structure and friction processes of the Punchbowl fault, San Andreas system, California. Tectonophysics 295:199-221

Chester FM, Logan JM (1986) Implications for mechanical properties of brittle faults from observations of the Punchbowl Fault Zone, California. Pure Appl Geophys 124:79-106

Chouet B (1988) Resonance of a fluid-driven crack - radiation properties and implications for the source of longperiod events and harmonic tremor. J Geophys Res 93:4375-4400

Chouet BA (1996) Long-period volcano seismicity: Its source and use in eruption forecasting. Nature 380:309316

Crider JG, Peacock DCP (2004) Initiation of brittle faults in the upper crust: a review of field observations. J Struct Geol 26:691-707

Curewitz D, Karson JA (1999) Ultracataclasis, sintering, and frictional melting in pseudotachylites from East Greenland. J Struct Geol 21:1693-1713

Denlinger RP, Hoblitt RP (1999) Cyclic eruptive behavior of silicic volcanoes. Geology 27:459-462

Dieterich JH (1979) Modeling of rock friction 1. experimental results and constitutive equations. J Geophys Res 84:2161-2168

Dingwell DB (1996) Volcanic dilemma: Flow or blow? Science 273:1054-1055

Dingwell DB (1997) The brittle-ductile transition in high-level granitic magmas: Material constraints. J Petrol $38: 1635-1644$

Dingwell DB, Webb SL (1989) Structural relaxation in silicate melts and non-Newtonian melt rheology in geologic processes. Phys Chem Min 16:508-516

Fabbri O, Lin AM, Tokushige H (2000) Coeval formation of cataclasite and pseudotachylite in a Miocene forearc granodiorite, southern Kyushu, Japan. J Struct Geol 22:1015-1025

Gil Cruz F, Chouet BA (1997) Long-period events, the most characteristic seismicity accompanying the emplacement and extrusion of a lava dome in Galeras Volcano, Colombia, in 1991. J Volcanol Geotherm Res $77: 121-158$

Gonnerman HM, Manga M (2003) Explosive volcanism may not be an inevitable consequence of magma fragmentation. Nature 426:432-435

Goto A (1999) A new model for volcanic earthquake at Unzen Volcano: Melt rupture model. Geophys Res Lett 26:2541-2544

Gottsmann J, Dingwell DB (2002) The thermal history of a spatter-fed lava flow: the 8-ka pantellerite flow of Mayor Island, New Zealand. Bull Volcanol 64:410-422

Gottsmann J, Giordano D, Dingwell DB (2002) Predicting shear viscosity during volcanic processes at the glass transition: a calorimetric calibration. Earth Planet Sci Lett 198:417-427

Gratier JP, Renard F, Labaume P (1999) How pressure solution creep and fracturing processes interact in the upper crust to make it behave in both a brittle and viscous manner. J Struct Geol 21:1189-1197

Hammer JE, Cashman KV, Voight B (2000) Magmatic processes revealed by textural and compositional trends in Merapi dome lavas. J Volcanol Geotherm Res 100:165-192

Heiken G, Wohletz K, Eichelberger J (1988) Fracture fillings and intrusive pyroclasts, Inyo Domes, California. J Geophys Res 93:4335-4350

Hidayat D, Voight B, Langston C, Ratdomopurbo A, Ebeling C (2000) Broadband seismic experiment at Merapi Volcano, Java, Indonesia: very-long-period pulses embedded in multiphase earthquakes. J Volcanol Geotherm Res 100:215-231 


\section{Fault textures in volcanic conduits}

Hill DP, Reasenberg PA, Michael A, Arabaz W, Beroza GC, Brune JN, D., Brumbaugh D, Davis S, DePolo D, Ellsworth WL, Gomberg J, Harmsen S, House L, Jackson SM, Johnston M, Jones L, Keller R, Malone S, Nava S, Pechmann JC, Sanford A, Simpson RW, Smith RS, Stark M, Stickney M, Walter S, Zollweg J, (1993) Seismicity remotely triggered by the magnitude 7.3 Landers, California, earthquake. Science 260:1617-1623

Hobbs BE, Ord A, Teyssier C (1986) Earthquakes in the ductile regime. Pure Appl Geophys 124:309-336

Jaupart C (1998) Gas loss from magmas through conduit walls during eruption. Geol Soc London Spec Pub $145: 73-90$

Jousset P, Neuberg J, Sturton S (2003) Modelling the time-dependent frequency content of low-frequency volcanic earthquakes. J Volcanol Geotherm Res 128:201-223

Karner SL, Marone C (1998) The effect of shear load on frictional healing in simulated fault gouge. Geophys Res Lett 25:4561-4564

Kilburn CRJ (2003) Multiscale fracturing as a key to forecasting volcanic eruptions. J Volcanol Geotherm Res 125:271-289

Kumagai H, Chouet BA (2000) Acoustic properties of a crack containing magmatic or hydrothermal fluids. J Geophys Res 105:25493-25512

Lahr JC, Chouet BA, Stephens CD, Power JA, Page RA (1994) Earthquake classification, location, and error analysis in a volcanic environment: implications for the magmatic system of the 1989-1990 eruptions at Redoubt volcano, Alaska. J Volcanol Geotherm Res 62:137-151

Lamontagne M, Ranalli G (1996) Thermal and rheological constraints on the earthquake depth distribution in the Charlevoix, Canada, intraplate seismic zone. Tectonophysics 257:55-69

Lin AM (1996) Injection veins of crushing-originated pseudotachylite and fault gouge formed during seismic faulting. Eng Geol 43:213-224

Lin AM (1999) Roundness of clasts in pseudotachylites and cataclastic rocks as an indicator of frictional melting. J Struct Geol 21:473-478

Luan FC, Paterson MS (1992) Preparation and deformation of synthetic aggregates of quartz. J Geophys Res 97:301-320

Manley CR (1996) In situ formation of welded tuff-like textures in the carapace of a voluminous silicic lava flow, Owyhee County, SW Idaho. Bull Volcanol 57:672-686

Marone C (1998) The effect of loading rate on static friction and the rate of fault healing during the earthquake cycle. Nature 391:69-72

Marone C, Scholz CH (1989) Particle-size distribution and microstructures within simulated fault gouge. J Struct Geol 11:799-814

Mastin LG (2002) Insights into volcanic conduit flow from an open-source numerical model. Geochemistry, Geophysics, Geosystems 3(7), 1037, doi:10.1029/2001GC000192

Mastin LG (submitted manuscript) The controlling effect of viscous dissipation on magma flow within silicic conduits. J Volcanol Geotherm Res, in review

McGarvie DW (1984) Torfajokull - a volcano dominated by magma mixing. Geology 12:685-688

Melosh HJ (1996) Dynamical weakening of faults by acoustic fluidization. Nature 379:601-606

Miller AD, Stewart RC, White RA, Luckett R, Baptie BJ, Aspinall WP, Latchman JL, Lynch LL, Voight B (1998) Seismicity associated with dome growth and collapse at the Soufrière Hills Volcano, Montserrat. Geophys Res Lett 25:3401-3404 


\section{Fault textures in volcanic conduits}

Molina I, Kumagai H, Yepes H (2004) Resonances of a volcanic conduit triggered by repetitive injections of an ash-laden gas. Geophys Res Lett 31, L03603, doi:10.1029/2003GL018934

Monzawa N, Otsuki K (2003) Comminution and fluidization of granular fault materials: implications for fault slip behavior. Tectonophysics 367:127-143

Neuberg J (2000) Characteristics and causes of shallow seismicity in andesite volcanoes. Phil Trans Roy Soc London A 358:1533-1546

Neuberg J, Tuffen H, Jolly A, Green D (2003) A trigger mechanism for volcanic low-frequency seismic events on Montserrat. Eos Trans AGU 84(46), Fall Meet Suppl, Abstract V31B-01

O'Hara KD (2001) A pseudotachylyte geothermometer. J Struct Geol 23:1345-1357

Otsuki K, Monzawa N, Nagase T (2003) Fluidization and melting of fault gouge during seismic slip: Identification in the Nojima fault zone and implications for focal earthquake mechanisms. J Geophys Res 108 108:2192-2208

Quane S, Russell J (2003) Microstructural analysis of welding: deformation and strain. Eos Trans AGU 84(46), Fall Meet Suppl, Abstract V12A-0552

Rust AC, Manga M, Cashman KV (2003) Determining flow type, shear rate and shear stress in magmas from bubble shapes and orientations. J Volcanol Geotherm Res 122:111-132

Scholz CH (1998) Earthquakes and friction laws. Nature 391:37-42

Shimamoto T (1986) Transition between frictional slip and ductile flow for halite shear zones at room temperature. Science 231:711-714

Sibson RH (1975) Generation of pseudotachylite by ancient seismic faulting. Geophys J Roy Astronom Soc 43:775-794

Sibson RH (1986) Brecciation processes in fault zones - inferences from earthquake rupturing. Pure Appl Geophys 124:159-175

Simpson C (1986) Fabric development in brittle-to-ductile shear zones. Pure Appl Geophys 124:269-288

Smith JV (2002) Structural analysis of flow-related textures in lavas. Earth Sci Rev 57:279-297

Smith JV, Miyake Y, Oikawa T (2001) Interpretation of porosity in dacite lava domes as ductile- brittle failure textures. J Volcanol Geotherm Res 112:25-35

Sparks RSJ, Tait SR, Yanev Y (1999) Dense welding caused by volatile resorption. J Geol Soc London 156:217225

Stasiuk MV, Barclay J, Carroll MR, Jaupart C, Ratte JC, Sparks RSJ, Tait SR (1996) Degassing during magma ascent in the Mule Creek vent (USA). Bull Volcanol 58:117-130

Stel H (1986) The effect of cyclic operation of brittle and ductile deformation on the metamorphic assemblage in cataclasites and mylonites. Pure Appl Geophys 124:289-307

Stesky RM, Brace WF, Riley DK, Robin PY (1974) Friction in faulted rock at high temperature and pressure. Tectonophysics 23:177-203

Stix J, Torres R, Narvaez L, Cortes GP, Raigosa J, Gomez D, Castonguay R (1997) A model of vulcanian eruptions at Galeras volcano, Colombia. J Volcanol Geotherm Res 77:285-303

Sturton S, Neuberg J (2003) The effects of a decompression on seismic parameter profiles in a gas-charged magma. J Volcanol Geotherm Res 128:187-199

Takagi H, Goto K, Shigematsu N (2000) Ultramylonite bands derived from cataclasite and pseudotachylyte in granites, northeast Japan. J Struct Geol 22:1325-1339 
Tuffen H (2001) Subglacial rhyolite volcanism at Torfajökull, Iceland. Unpublished PhD thesis, Open University, Milton Keynes, UK, 381 p

Tuffen H, McGarvie DW, Pinkerton H, Gilbert JS (2002a) Physical volcanology of a subglacial-to-emergent rhyolitic tuya at Rauðufossafjöll, Torfajökull, Iceland. Geol Soc London Spec Pub 202:213-236

Tuffen H, Dingwell DB, Pinkerton H, Davison B (2002b) Multiple generations of tuffisite veins record repetitive ductile-brittle deformation of rhyolitic magma rising within an effusive vent: a source of flow banding in silicic lavas and repetitive seismic signals? (Abstract). Eos Trans AGU 83:47, Fall Meet Suppl, Abstract V12A-1416

Tuffen H, Dingwell DB, Pinkerton H (2003) Repeated fracture and healing of silicic magma generates flow banding and earthquakes? Geology 31:1089-1092

Uchida N, Sakai T (2002) Analysis of peculiar volcanic earthquakes at Satsuma-Iojima volcano. Earth Planets Space 54:197-209

Umakoshi K, Shimizu H, Matsuwo N (2002) Seismic activity associated with the growth of the lava dome at Unzen Volcano (November 1993 - January1994) - Grouping of earthquakes on the basis of cross-correlations among their waveforms. Bull Volcanol Soc Japan 47:43-55 (in Japanese)

Umakoshi K, Shimizu H, Matsuwo N (2003) Seismic activity associated with the endogenous growth of lava dome at Unzen Volcano, Japan. Abstract V10/01A/D-014, IUGG XXIII meeting, Sapporo, Japan

Vermilye JM, Scholz CH (1998) The process zone: A microstructural view of fault growth. J Geophys Res 103:12223-12237

Vernon RH (1987) A microstructural indicator of shear sense in volcanic-rocks and its relationship to porphyroblast rotation in metamorphic rocks. J Geol 95:127-133

Voight B, Sparks RSJ, Miller AD, Stewart RC, Hoblitt RP, Clarke A, Ewart J, Aspinall WP, Baptie B, Calder ES, Cole P, Druitt TH, Hartford C, Herd RA, Jackson P, Lejeune AM, Lockhart AB, Loughlin SC, Luckett R, Lynch L, Norton GE, Robertson R, Watson IM, Watts R, Young SR (1999) Magma flow instability and cyclic activity at Soufriere Hills Volcano, Montserrat, British West Indies. Science 283:1138-1142

Warr LN, van der Pluijm BA, Peacor DR, Hall CM (2003) Frictional melt pulses during a similar to $1.1 \mathrm{Ma}$ earthquake along the Alpine Fault, New Zealand. Earth Planet Sci Lett 209:39-52

Webb SL, Dingwell DB (1990) Non-Newtonian rheology of igneous melts at high stresses and strain rates experimental results for rhyolite, andesite, basalt, and nephelinite. J Geophys Res 95:15695-15701

Westrich HR, Eichelberger JC (1994) Gas-transport and bubble collapse in rhyolitic magma - an experimental approach. Bull Volcanol 56:447-458

White RA, Miller AD, Lynch L, Power J (1998) Observations of hybrid seismic events at Soufriere Hills Volcano, Montserrat: July 1995 to September 1996. Geophys Res Lett 25:3657-3660

Wilson JE, Chester JS, Chester FM (2003) Microfracture analysis of fault growth and wear processes, Punchbowl Fault, San Andreas System, California. J Struct Geol 25:1855-1873 
Fault textures in volcanic conduits

\section{Figure 1.}

(a) Map showing the location and simplified structure of Torfajökull central volcano, which is located at the southern terminus of the Eastern Rift Zone (ERZ) in southern Iceland.

(b) Simplified map of southeast Rauðufossafjoll, indicating the position of the conduits (Th - Thumall, $S$ - Skriðugil) and the subaerial lava flows. Different flow units are indicated $(1,2,3)$; the conduits fed part of unit 2. The conduits are parallel to the long axis of lava unit 2 and the ridge crest, which are thought to indicate the fissure orientation (Tuffen 2001).

Figure 2. Overview of the two conduits. The main textural zones indicated are A - vesicular obsidian, B - vesicle-free obsidian, C - spherulitic obsidian breccia, D - spherulitic rhyolite.

(a) Thumall conduit seen from the south. Dark obsidian walls (B) enclose a spherulitic interior (D). Near-vertical joints in the interior are parallel to the flow direction. The position of Skriðugil Conduit, over the right-hand horizon, is indicated (S).

(b) Skriðugil Conduit seen from the north. Vesicle-free obsidian (B) encloses vesicular obsidian (A) in the scree gully, which corresponds to the conduit centre. Near-vertical flow structures in the conduit are discordant with those in the lava flows, and parallel to the ridge crest. Thumall conduit (Th) is just out of sight behind the cliff of rhyolite.

Figure 3. Phase 1 initial fractures in the field. Note the paucity of intact phenocrysts (pale white) in the fracture-filling material. 
Fault textures in volcanic conduits

(a) A network of fractures in the western obsidian of Thumall Conduit, modified from Tuffen et al. (2003). Injection veins (I) and a small reservoir zone (R) branch from an irregularly shaped main fault vein $(F)$.

(b) An irregular reservoir zone $(R)$ within a fault vein network $(F)$. Contorted bedding in the reservoirfilling cataclasite (arrow) is continuous into the narrow vein branching to the left, and is thought to be a sedimentary structure formed by transport of a gas-particle mixture through the fracture system.

Cataclasite was generated on fault veins and injection veins, and accumulated in void-like reservoir zones (Sibson 1975, Curewitz and Karson 1999). Offset markers on the walls of the bottom left fault vein indicate thrust displacement of $12 \mathrm{~mm}$ (arrows).

(c) A typical fracture network in the central part of Skriðugil Conduit, showing injection veins (I) in the walls of fault veins $(F)$, and a $40 \mathrm{~mm}$ wide reservoir zone (bottom right, $R$ ). The white arrows indicate opening of an injection vein (I). D is a truncated displacement marker in the fault vein wall.

\section{Figure 4.}

(a) A typical phase 2 banded cataclasite zone in thin section, photographed in plane-polarised light. The dark bands adjacent to the surrounding obsidian consist of ultracataclasite, and some larger clasts are cut by small fractures (arrow), indicating in-situ grain size reduction. The cataclasite zone is around $2 \mathrm{~mm}$ thick. Although internal banding is locally deflected around a phenocryst protruding from the surrounding obsidian $(\mathrm{P})$, it is mostly parallel to the zone margins.

(b) Handspecimen photograph of Riedel shear textures in a $20 \mathrm{~mm}$ thick phase 2 cataclasite zone. The palest coloured material is ultracataclasite on a $2 \mathrm{~mm}$ thick Riedel shear band (RS).

(c) Thin section photograph in plane-polarised light showing the internal structure of the $2 \mathrm{~mm}$ thick Riedel shear band shown in (b). Based on clast orientations, three different generations of crosscutting shear zones can be identified (labelled), the youngest being the ultracataclasite band 3 . The letter $\mathrm{D}$ indicates where ultracataclasite is deflected around clasts within cohesive, foliated cataclasite.

\section{Figure 5.}

(a) Deformed phase 3 cataclasite bands within obsidian, west side of Thumall conduit. Tightly-folded injection veins ( $\mathrm{I})$ and a less-deformed reservoir zone $(\mathrm{R})$ are visible. Fold geometries are complex, with similar, concentric, and buckle folds of variable wavelength. 
Fault textures in volcanic conduits

(b) Thin section photomicrograph in plane-polarised light showing complex buckle folds within a deformed cataclasite zone (phase 3). Different band colours are due to varying concentrations of metallic oxide microlites. The colourless material around the band is microlite-free obsidian. Note the disharmonic folding of the central pale band and deflection of folds around phenocrysts. Bulbous folds in the cataclasite at $\mathrm{x}$, with cusps of obsidian between them, indicate that the cataclasite was more viscous than the surrounding obsidian. However, fold shapes at y are more difficult to interpret, and suggest similar layer viscosities. The box indicates the position of (c).

(c) Close up of a buckle fold from (b) in plane-polarised light. Highly-deformed large clasts are visible as pale streaks in the cataclasite (arrow). The presence of phenocryst fragments and the cuspate form of the finger of colourless intact obsidian within the fold suggest that the cataclasite was more viscous. (d) Field photograph of deformed cataclasite from the west side of Thumall Conduit. Such bands are near-vertical, continuous over metres and morphologically similar to phase 2 cataclasite zones. Note the proximity of near-planar bands ( $\mathrm{pl}$ ) to folded, shortened bands (cr). Pale grey bands, such as the band at the left margin of the band labelled $\mathrm{pl}$, consist of ultracataclasite.

Figure 6. Textures within phase 4 a cataclasite.

(a) Thin section photograph of highly sheared cataclasite band, showing elongate, viscously deformed glass particles, which are commonly themselves folded $(F)$. White patches are phenocryst fragments, and the pale, isotropic body at the bottom is obsidian, which is locally spherulitic, contains blade-like microlites, and may have been generated by frictional melting (equivalent to glassy pseudotachylite of Curewitz and Karson, 1999). Taken in plane-polarised light.

(b) Close-up of boundaries between highly-deformed clasts in annealed cataclasite in thin section, plane-polarised light. Although all clasts are glassy and texturally indistinguishable from each other, their margins are defined by trails of $10-50 \mu \mathrm{m}$ microlites.

(c) Scanned image of a thin section from the eastern side of Thumall Conduit, showing many phase 4 cataclasite zones in different stages of annealing within obsidian. Phase 4a: individual clasts are distinguishable within the dark zone with abundant phenocryst fragments on the left, labelled a, as well as banding within the zone. Phase $4 \mathrm{~b}$ : although internal banding is visible within zones labelled $b$, which are deflected around phenocrysts, microlites are evenly distributed within bands, and contacts between former clasts have been destroyed. Phase 4c: pale bands, labelled c, are enriched in microlites with respect to the surrounding obsidian, but both evidence for individual clasts and internal 
Fault textures in volcanic conduits

banding are absent. (d) Photomicrograph in plane-polarised light of dashed box in (c), showing deflection of a banded cataclasite zone around a phenocryst. The darkest band, labelled $u$, has the highest number density of microlites and is an annealed ultracataclasite band. A thin pale band on the upper surface of the ultracataclasite band is microlite-poor and may have remelted.

(e) Close-up of box in (d), showing textures in the banded annealed cataclasite, plane-polarised light. The dark band, labelled $\mathrm{u}$, contains the highest number density of $<50 \mu \mathrm{m}$ metallic oxide microlites, which are randomly orientated. Note the sharp contact between the mid-grey band and the microlitepoor colourless obsidian (arrow), which corresponds to the margin of a phase 2 cataclasite band. (f) Structureless microlite-rich bands in obsidian are deflected around a pyroxene phenocryst. Such bands are almost ubiquitous in obsidian (e.g. Vernon 1987, Smith 2002). Photomicrograph taken in plane-polarised light.

Figure 7. Evidence for repeated fracture within the conduit obsidian.

(a) A small fracture network, comprising reservoir zones ( $p 1 r)$ and fault veins ( $p 1 f)$, cuts and displaces deformed cataclasite from an earlier fracture cycle. An annealed cataclasite zone ( $p 4 a)$ is offset by thrust displacement of $12 \mathrm{~mm}\left(\mathrm{X}-\mathrm{X}^{\prime}\right)$.

(b) Displacement of a folded phase 3 cataclasite zone (p3) by a small normal fault (arrows). Another fault (dashed line, left) also truncates deformed cataclasite. The fault surface is devoid of cataclasite material in this position and is irregular.

(c) Phase 2 cataclasite-ultracataclasite zone cutting phase 3 and $4 c$ cataclasite zones. A phenocryst in the p3 zone is truncated by the phase 2 zone. Clasts in the cataclasite are closely-packed and locally cut by small fractures, indicating in-situ grain size reduction. Photomicrograph in plane-polarised light. (d) An irregular, cataclasite-free fault surface (p1) truncates phase 2 cataclasite, which in turn truncates phase $4 a$ cataclasite (top left). The large glassy clast in phase 2 cataclasite is cut by a fracture that is filled with fine-grained matrix, indicating in-situ granulation and possible transport of fluidised material within newly formed microfractures. Photomicrograph in plane-polarised light.

Figure 8. Cartoon illustrating the different phases of seismic cycles within rising magma. S corresponds to fault vein, I to injection vein, $r$ to reservoir zone, and $u$ to ultracataclasite zone. 
Fault textures in volcanic conduits

Figure 9. Schematic representation of the seismic cycles in terms of the glass transition of the melt phase. The solid curves indicate the path of the magma in strain rate-temperature space during a seismic cycle. Magma viscosity decreases strongly with increasing temperature (Gottsmann et al. 2002).

(a) Initial fracture (1) brought about by cooling at a fixed viscous strain rate. The transition to localised frictional deformation leads to an increased strain rate and temperature increase (2). Frictional heating then leads to cohesive distributed deformation, leading to a drop in strain rate and a return to the liquid field $(3,4)$. On further cooling, the cycle may repeat.

(b) In this model, the initial fracture is triggered by an increase in strain rate, which further increases during localised slip (2). Frictional heating and compaction then led to distributed deformation and a decreased strain rate (3), and eventually a return to the liquid field (4). Another strain rate increase would trigger another cycle. 
Fault textures in volcanic conduits

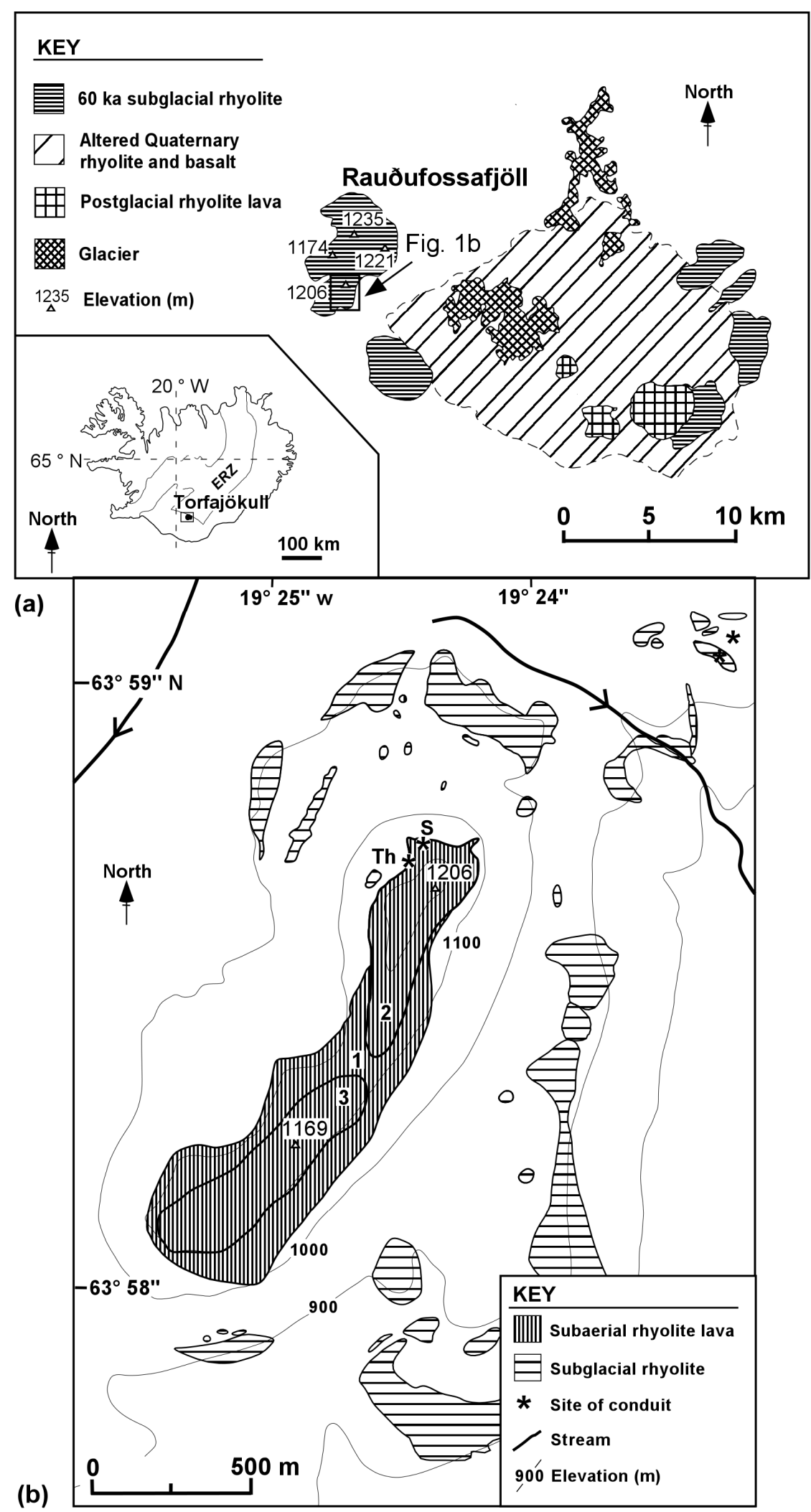

Figure 1 
Fault textures in volcanic conduits
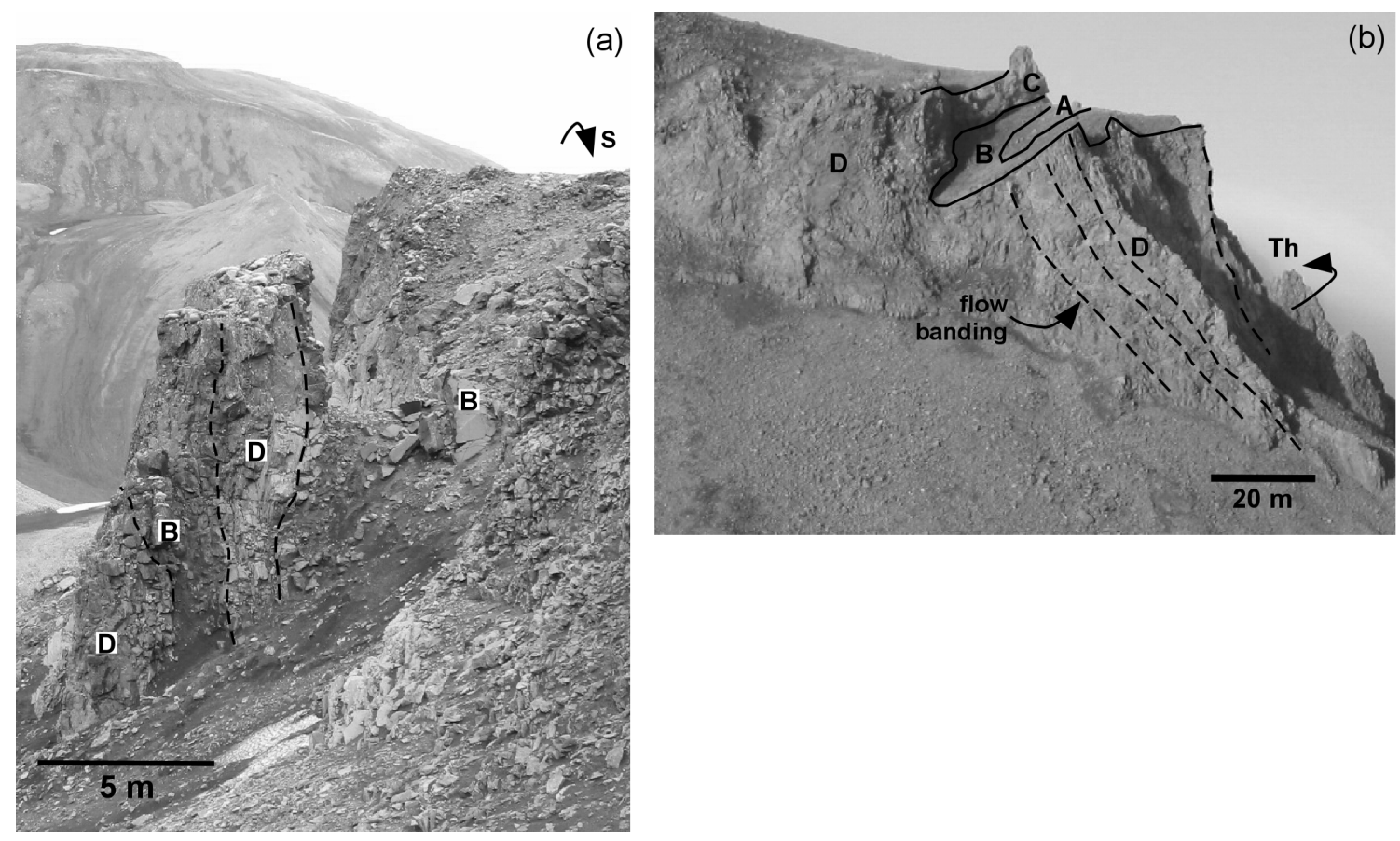

Figure 2 
Fault textures in volcanic conduits

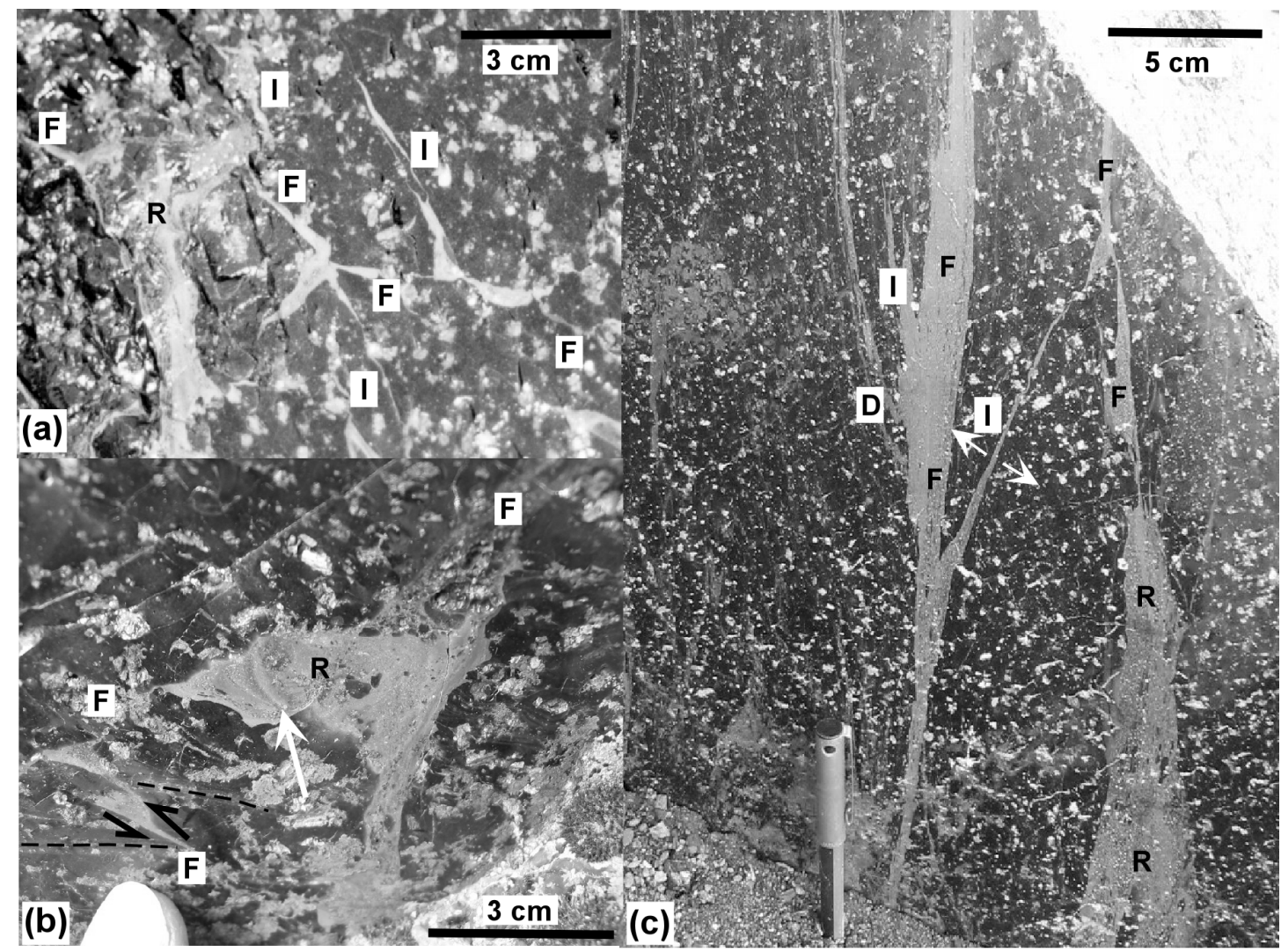

Figure 3 
Fault textures in volcanic conduits

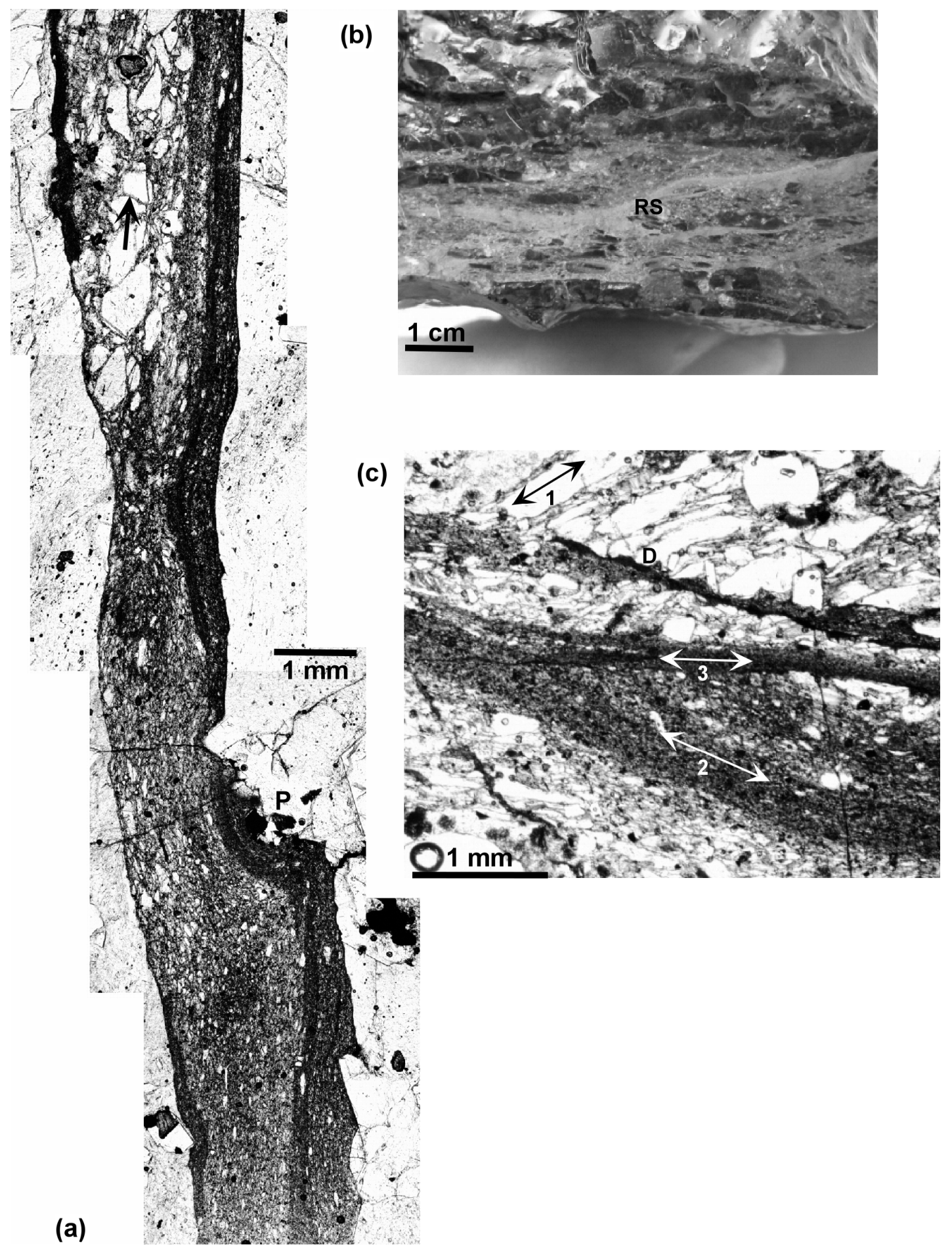

Figure 4 
Fault textures in volcanic conduits

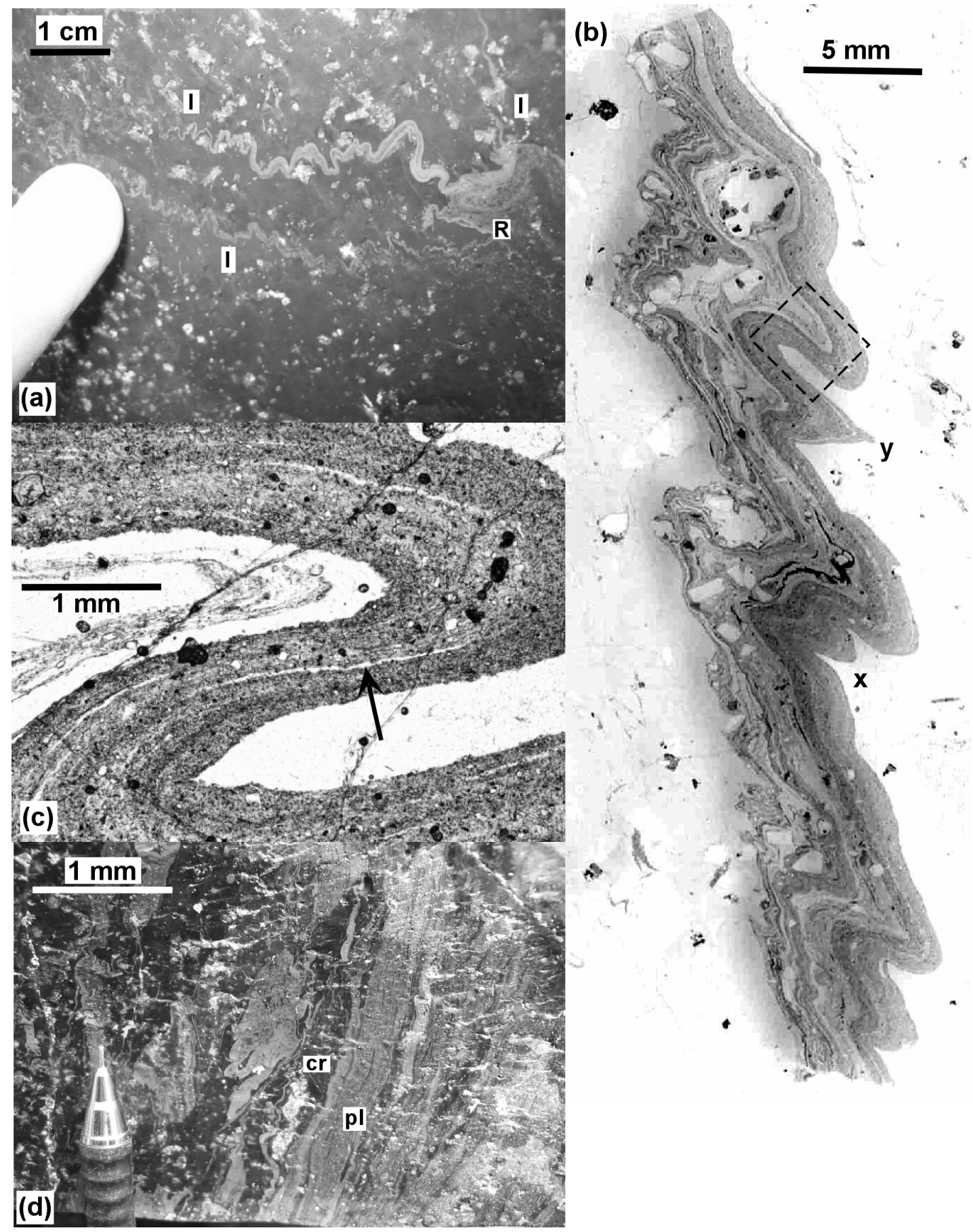

Figure 5 
Fault textures in volcanic conduits

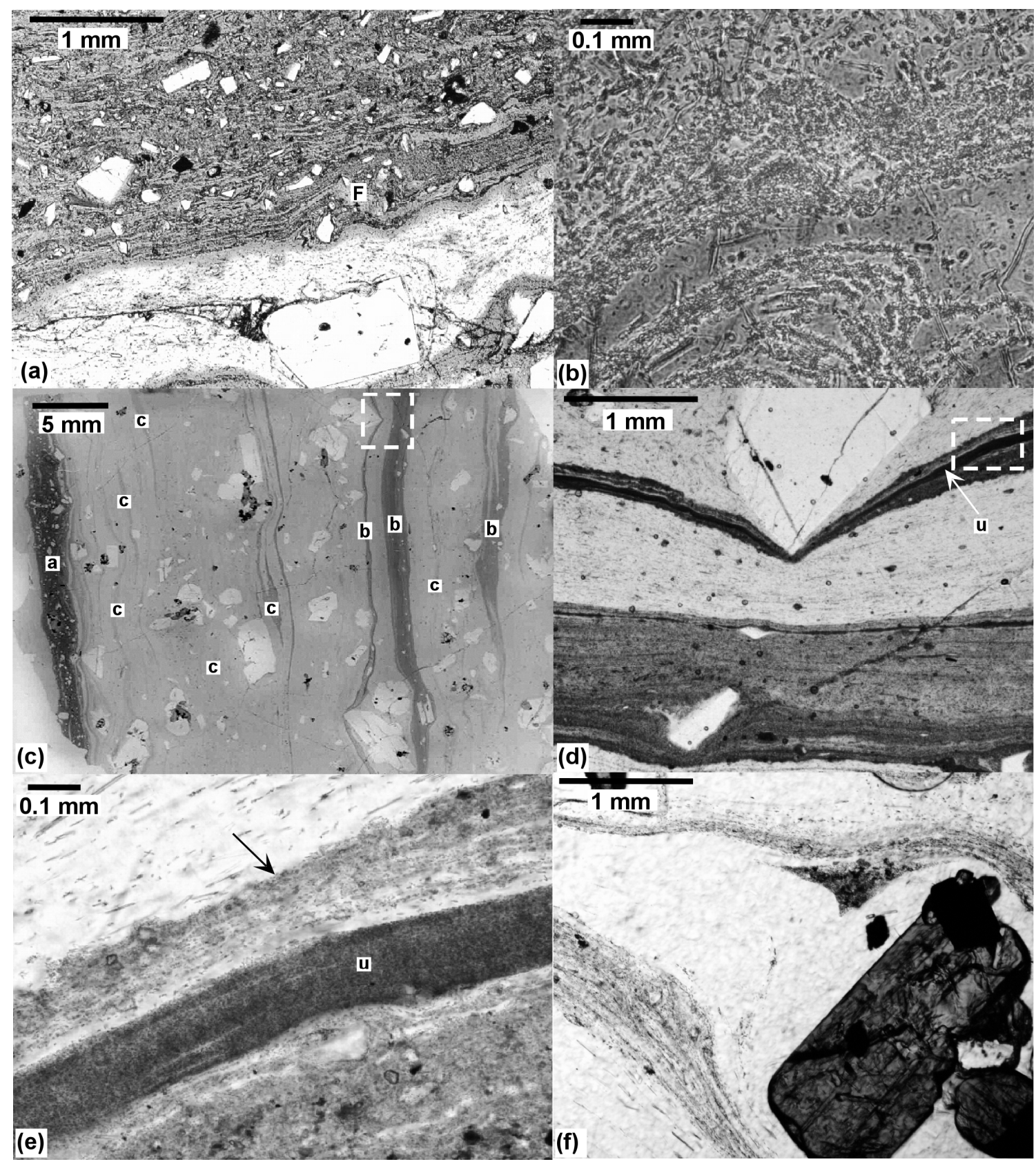

Figure 6 


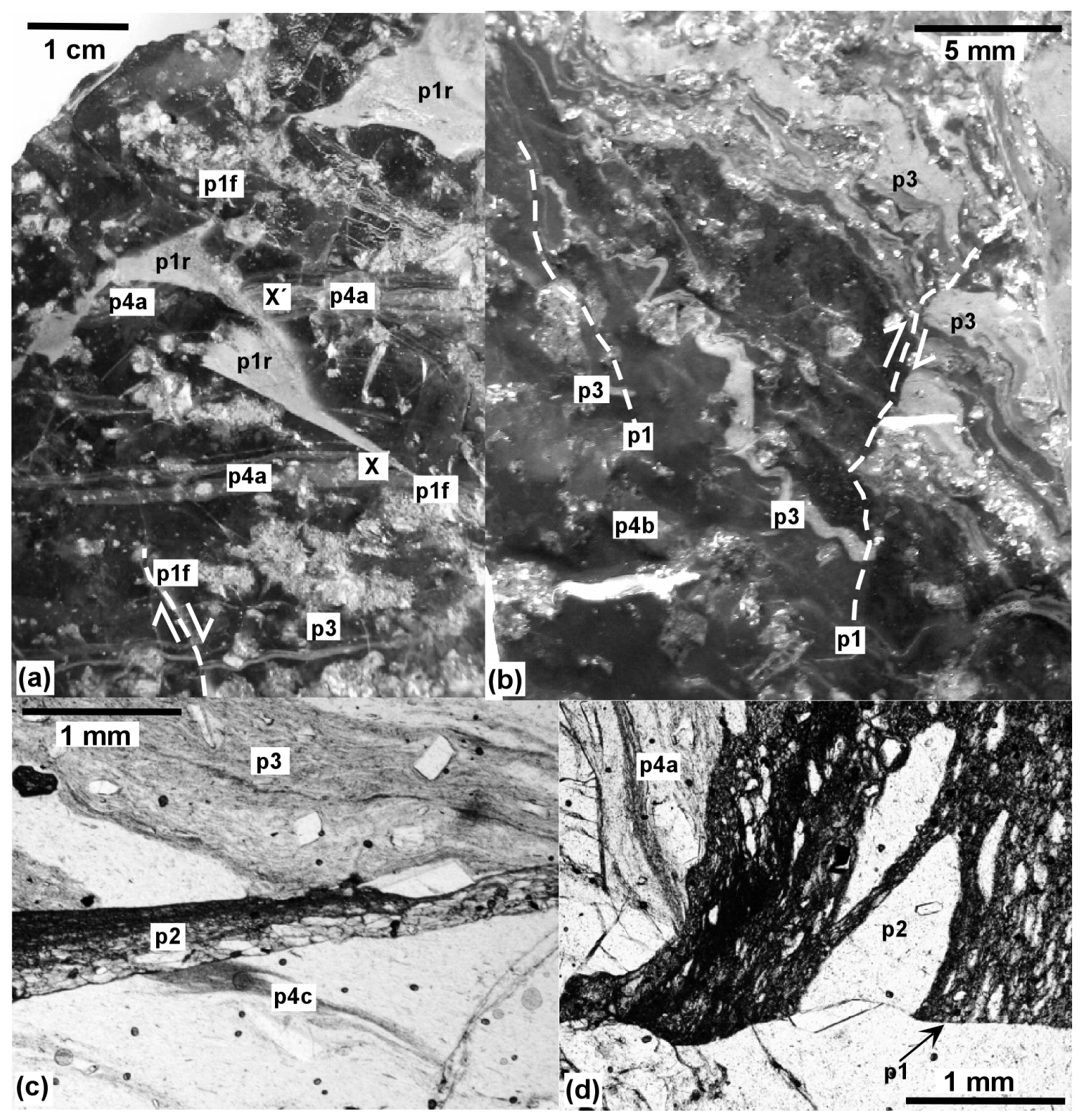

Figure 7 
Fault textures in volcanic conduits

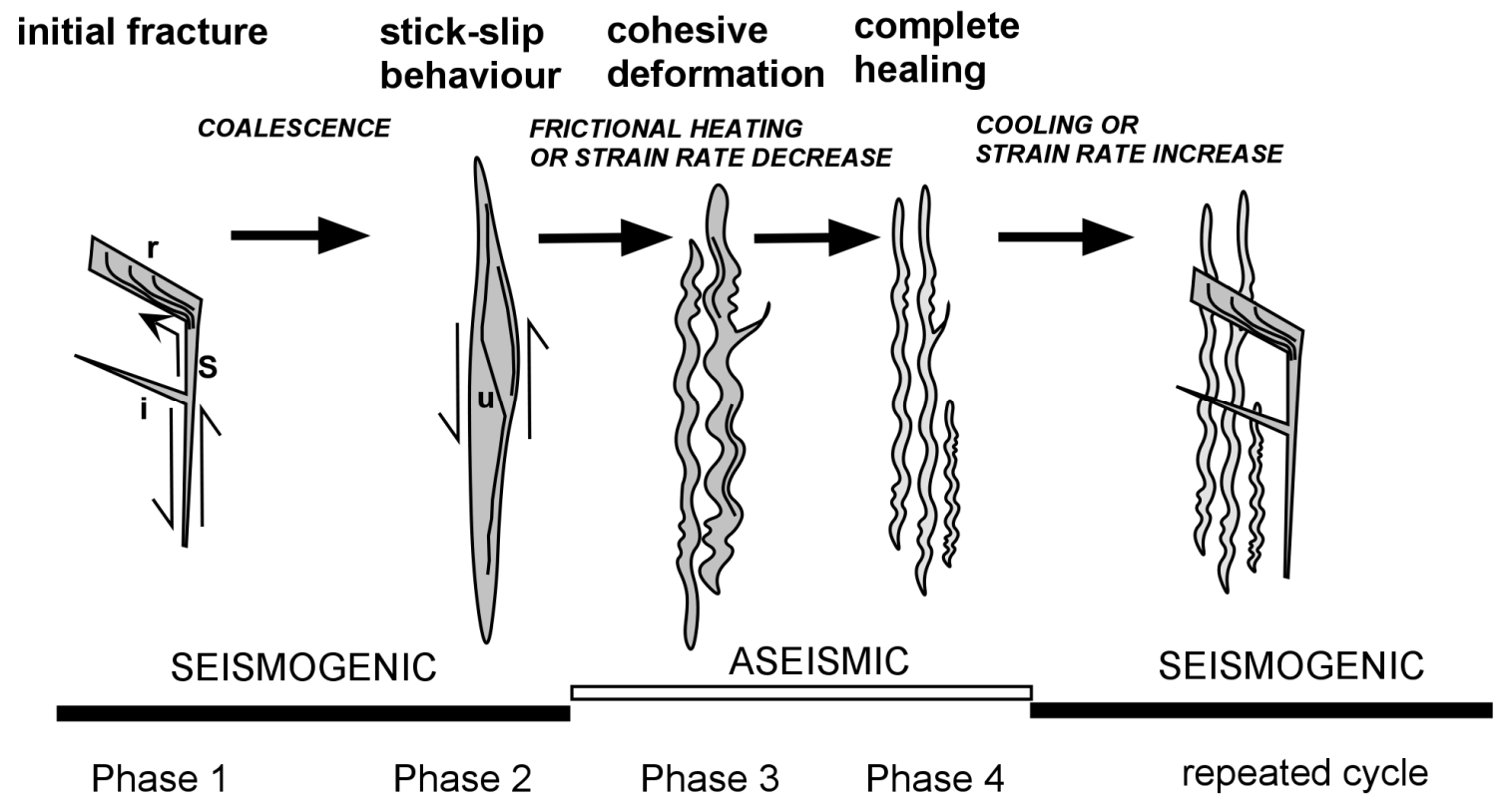

Figure 8 
Fault textures in volcanic conduits
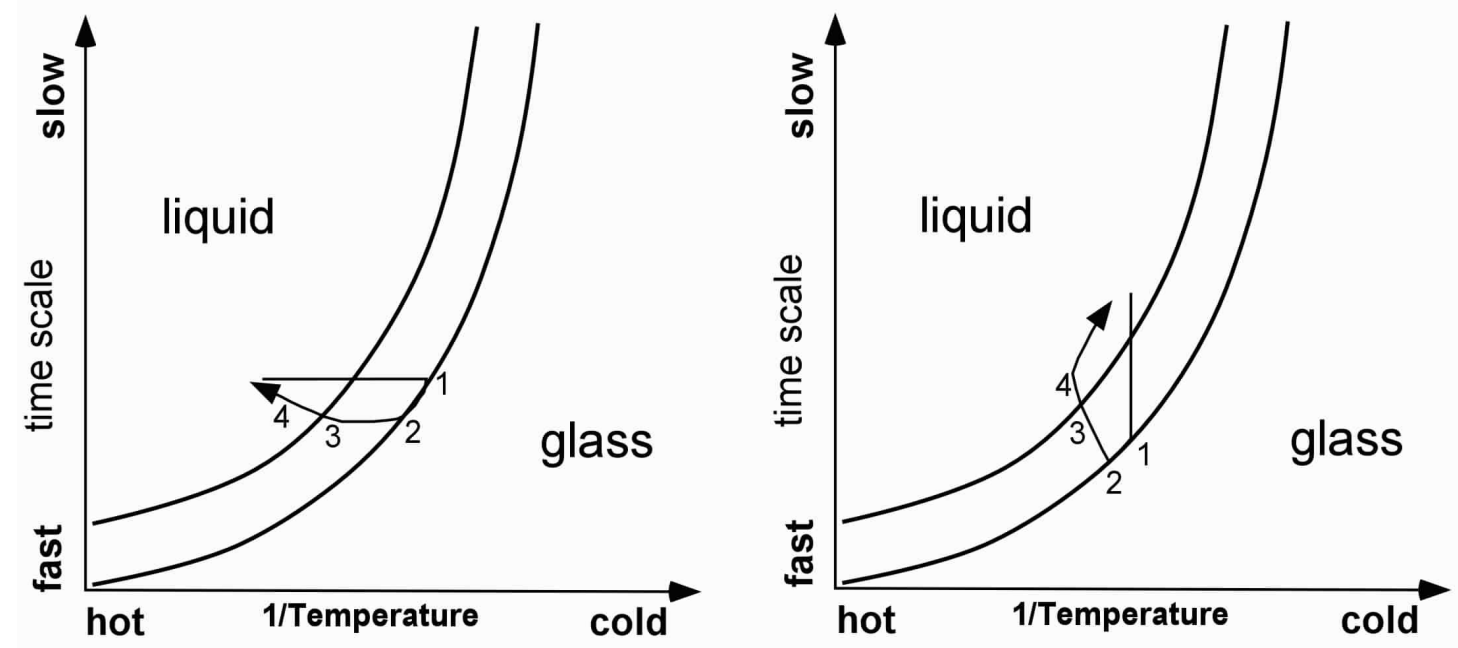

(a)

(b)

Figure 9 